Biogeosciences Discuss., doi:10.5194/bg-2016-300, 2016

Manuscript under review for journal Biogeosciences

Published: 21 July 2016

(c) Author(s) 2016. CC-BY 3.0 License.

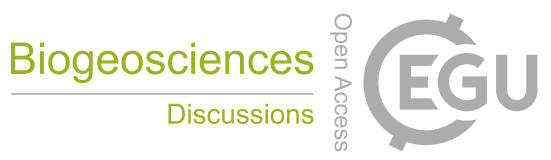

(c) (1)

\title{
Anaerobic methane oxidation in an East African great lake (Lake Kivu)
}

Fleur A. E. Roland ${ }^{1 *}$, François Darchambeau ${ }^{1}$, Cédric Morana ${ }^{2}$, Sean A. Crowe ${ }^{3}$, Bo

Thamdrup ${ }^{4}$ and Alberto V. Borges ${ }^{1}$

5

${ }^{1}$ Chemical Oceanography Unit, Université de Liège, Belgium

${ }^{2}$ Department of Earth and Environmental Sciences, Katholieke Universiteit Leuven (KU Leuven),

Belgium

${ }^{3}$ Department of Earth, Ocean and Atmospheric Sciences, University of British Columbia, Canada

10

${ }^{4}$ Institute of Biology and Nordic Center for Earth Evolution, University of Southern Denmark, Denmark

*Corresponding author: froland@ulg.ac.be 
Biogeosciences Discuss., doi:10.5194/bg-2016-300, 2016

Manuscript under review for journal Biogeosciences

Published: 21 July 2016

(c) Author(s) 2016. CC-BY 3.0 License.

\section{Abstract}

This study investigates methane $\left(\mathrm{CH}_{4}\right)$ oxidation in the water column of Lake Kivu, a deep meromictic tropical lake containing large quantities of $\mathrm{CH}_{4}$ in the anoxic deep waters. Depth profiles of dissolved gases $\left(\mathrm{CH}_{4}\right.$ and nitrous oxide $\left(\mathrm{N}_{2} \mathrm{O}\right)$ ) and of the different potential electron acceptors for anaerobic methane oxidation (AOM) (nitrate, sulfate, iron and manganese) were determined during six field campaigns between June 2011 and August 2014. Bacterial abundance all along the vertical profiles was also determined by flow cytometry during three field campaigns, and denitrification measurements based on stable isotopes were performed twice. Incubation experiments were performed to quantify $\mathrm{CH}_{4}$ oxidation and nitrate consumption rates, with a focus on AOM, without and with an inhibitor of sulfate-reducing bacteria activity (molybdate). Nitrate consumption rates were measured in these incubations. Substantial $\mathrm{CH}_{4}$ oxidation activity was observed in oxic and anoxic waters, and in the upper anoxic waters of Lake Kivu, $\mathrm{CH}_{4}$ is a major electron donor to sustain anaerobic metabolic processes coupled to AOM. The maximum aerobic and anaerobic $\mathrm{CH}_{4}$ oxidation rates were estimated to $27 \pm 2$ and $16 \pm 8$ $\mu$ mol L $\mathrm{L}^{-1} \mathrm{~d}^{-1}$, respectively. We observed a decrease of AOM rates when molybdate was added for half of the measurements, strongly suggesting the occurrence of AOM linked to sulfate reduction, but an increase of AOM rates was observed for the other half. Nitrate reduction rates and dissolved manganese production rates tended to be higher with the addition of molybdate, but the maximum rates of $0.6 \pm 0.02$ and $11 \pm 2 \mu \mathrm{mol} \mathrm{L}^{-1} \mathrm{~d}^{-1}$, respectively, were never high enough to explain AOM rates observed at the same depths. We also put in evidence a difference in relative importance of aerobic and anaerobic $\mathrm{CH}_{4}$ oxidation between the seasons, with a higher importance of aerobic oxidation when the oxygenated layer was thicker (in dry season). 
Biogeosciences Discuss., doi:10.5194/bg-2016-300, 2016

Manuscript under review for journal Biogeosciences

Published: 21 July 2016

(c) Author(s) 2016. CC-BY 3.0 License.

\section{Introduction}

Due to its potential impact in global warming and its increase due to human activities, the biogeochemical cycle of methane $\left(\mathrm{CH}_{4}\right)$ raises great interest, and methanogenesis and methanotrophy have been widely studied in a large variety of environments. In natural environments, $\mathrm{CH}_{4}$ is produced anaerobically by methanogenic archaea. The total $\mathrm{CH}_{4}$ emission has been recently estimated to $553 \mathrm{Tg} \mathrm{CH}_{4} \mathrm{yr}^{-1}$ for the period 2000-2009, from which 64 $\%$ is emitted by tropical areas (Kirschke et al., 2013;Saunois et al., 2016). Previous studies estimated that 9.5\% of $\mathrm{CH}_{4}$ is released from tropical freshwaters and the rest from non-tropical freshwaters (13.5\%), marine ecosystems (3\%), human activities (63\%), plants (6\%), gaseous hydrates (2\%) and termites (3\%) (Conrad, 2009;Bastviken et al., 2011). The real amount of $\mathrm{CH}_{4}$ produced in these systems is higher, but a significant percentage is biologically oxidized (aerobically or anaerobically) before reaching the atmosphere (Bastviken et al., 2002). Anaerobic $\mathrm{CH}_{4}$ oxidation (AOM) has been widely observed in marine environments, where it is mainly coupled to sulfate $\left(\mathrm{SO}_{4}{ }^{2-}\right)$ reduction (e.g. Iversen and Jørgensen, 1985;Boetius et al., 2000;Jørgensen et al., 2001). In freshwaters environments, AOM has been less studied and is often considered as negligible compared to aerobic $\mathrm{CH}_{4}$ oxidation due to lower $\mathrm{SO}_{4}{ }^{2-}$ concentrations than in seawater (Rudd et al., 1974). However, other potential electron acceptors for AOM, such as nitrate $\left(\mathrm{NO}_{3}^{-}\right)$, iron (Fe) and manganese (Mn) (Borrel et al., 2011;Cui et al., 2015), can potentially be found in non-negligible concentrations in freshwater environments. Further, in hardwater, saline and volcanic lakes $\mathrm{SO}_{4}{ }^{2-}$ can be abundant.

Lake Kivu is a deep (maximum depth: 485 m) meromictic lake characterized by a high amount of $\mathrm{CH}_{4}$ $\left(60 \mathrm{~km}^{3}\right.$ at $0^{\circ} \mathrm{C}$ and $\left.1 \mathrm{~atm}\right)$ dissolved in its deep anoxic waters. Paradoxically, this lake is a very low emitter of $\mathrm{CH}_{4}$ to the atmosphere due to intense $\mathrm{CH}_{4}$ oxidation (Borges et al., 2011;Roland et al., 2016a). It is divided in different basins and bays. In the water column of the main basin, $\mathrm{SO}_{4}{ }^{2-}$ concentrations are relatively high (100-200 $\mu \mathrm{mol} \mathrm{L}{ }^{-1}$; Morana et al., 2016) and a large $\mathrm{SO}_{4}{ }^{2-}$-reducing bacteria (SRB) community is present and co-occurs with methanotrophic archaea (İnceoğlu et al., 2015). The data based on 16S rRNA strongly suggest the occurrence of AOM coupled to $\mathrm{SO}_{4}{ }^{2-}$ reduction (SDMO), although it remains to be demonstrated in a direct way and quantified. Also, a $\mathrm{NO}_{3}{ }^{-}$accumulation zone (nitracline) is often present during the rainy season at the oxic-anoxic interface (Roland et al., 2016a), and can thus potentially contribute to $\mathrm{CH}_{4}$ oxidation. Based on these observations, we hypothesize that $\mathrm{SO}_{4}{ }^{2-}$ could be the unique electron acceptor involved in AOM during the dry season, while AOM coupled with $\mathrm{NO}_{3}{ }^{-}$reduction (NDMO) could also contribute during the rainy season at a lower extent. Potential AOM linked to Fe and Mn reduction will also be investigated.

\section{Material and methods}

\subsection{Sampling sites}

Lake Kivu is an East African great lake located at the border between Rwanda and the Democratic Republic of the Congo (Fig. 1). It is divided into one main basin, two small basins and two bays: Northern Basin (or main basin), Southern Basin (or Ishungu Basin), Western Basin (or Kalehe Basin), the bay of Kabuno in the north and the bay of Bukavu in the South.

Six field campaigns were conducted in the main basin (the Northern Basin off Gisenyi; $-1.72504^{\circ} \mathrm{N}$, $29.23745^{\circ} \mathrm{E}$ ) in June 2011 (early dry season), February 2012 (rainy season), October 2012 (late dry season), May 2013 (late rainy season), September 2013 (dry season) and August 2014 (dry season). 
Biogeosciences Discuss., doi:10.5194/bg-2016-300, 2016

Manuscript under review for journal Biogeosciences

Published: 21 July 2016

(c) Author(s) 2016. CC-BY 3.0 License.

\subsection{Physico-chemical parameters and sampling}

Vertical profiles of temperature, conductivity, $\mathrm{pH}$ and oxygen were obtained with a Yellow Springs Instrument $6600 \mathrm{~V} 2$ multiparameter probe. Water was collected with a 7L Niskin bottle (Hydro-Bios) every 2.5 $\mathrm{m}$ in $\mathrm{a} \sim 10 \mathrm{~m}$ zone centered at the oxic-anoxic interface.

\subsection{Chemical analyses}

Samples for $\mathrm{CH}_{4}$ and $\mathrm{N}_{2} \mathrm{O}$ concentrations, and $\mathrm{CH}_{4}$ oxidation measurements were collected in $60 \mathrm{ml}$ glass serum bottles, filled directly from the Niskin bottle with tubing, left to overflow, and sealed with butyl stoppers and aluminium caps. Two bottles were directly poisoned with $200 \mu \mathrm{l}$ of $\mathrm{HgCl}_{2}$ injected through the septum with a syringe. Ten other bottles were incubated in the dark and at constant temperature close to in situ temperature $\left(\sim 23^{\circ} \mathrm{C}\right)$. Five of them received $250 \mu \mathrm{l}$ of a solution of sodium molybdate $\left(1 \mathrm{~mol} \mathrm{~L}^{-1}\right.$, hence a final concentration of $4 \mathrm{mmol} \mathrm{L}^{-1}$ ), and five received no treatment. The bacterial activity of these ten bottles was stopped at 12, 24, 48, 72 and $96 \mathrm{~h}$ by the addition of $200 \mu \mathrm{l}$ of $\mathrm{HgCl}_{2}$. $\mathrm{CH}_{4}$ and $\mathrm{N}_{2} \mathrm{O}$ concentrations were determined via the headspace equilibration technique ( $20 \mathrm{~mL} \mathrm{~N}_{2}$ headspace in $50 \mathrm{~mL}$ serum bottles, for samples of the main basin) and measured by gas chromatography (GC) (Weiss, 1981) with electron capture detection (ECD) for $\mathrm{N}_{2} \mathrm{O}$ and with flame ionization detection (FID) for $\mathrm{CH}_{4}$, as described by (Borges et al., 2015). The SRI 8610C GC-ECD-FID was calibrated with certified $\mathrm{CH}_{4}: \mathrm{CO}_{2}: \mathrm{N}_{2} \mathrm{O}: \mathrm{N}_{2}$ mixtures (Air Liquide, Belgium) of 1, 10, 30 and 509 ppm $\mathrm{CH}_{4}$ and of $0.2,2.0$ and $6.0 \mathrm{ppm} \mathrm{N}_{2} \mathrm{O}$. Concentrations were computed using the solubility coefficients of Yamamoto et al. (1976) and Weiss and Price (1980), for $\mathrm{CH}_{4}$ and $\mathrm{N}_{2} \mathrm{O}$, respectively. The precision of measurements was $\pm 3.9 \%$ and $\pm 3.2 \%$ for $\mathrm{CH}_{4}$ and $\mathrm{N}_{2} \mathrm{O}$, respectively.

Samples for nutrients analyses were collected in $50 \mathrm{ml}$ plastic vials after being filtered through a $0.22 \mu \mathrm{m}$ syringe filter. $200 \mu \mathrm{l}$ of $\mathrm{H}_{2} \mathrm{SO}_{4} 5 \mathrm{~N}$ were added at each vial for preservation. Samples were then frozen. $\mathrm{NO}_{2}{ }^{-}$and $\mathrm{NO}_{3}{ }^{-}$concentrations were estimated by spectrophotometry. $\mathrm{NO}_{2}^{-}$concentrations were determined by the sulfanilamide coloration method (APHA 1998), using a 5-cm light path on a spectrophotometer Thermo Spectronic Genesys 10vis. $\mathrm{NO}_{3}{ }^{-}$concentrations were determined after vanadium reduction to $\mathrm{NO}_{2}{ }^{-}$and quantified under this form with a Multiskan Ascent Thermo Scientific multi-plates reader (APHA, 1998;Miranda et al., 2001). The detection limits for these methods were 0.03 and $0.15 \mu \mathrm{mol} \mathrm{L}^{-1}$ for $\mathrm{NO}_{2}{ }^{-}$and $\mathrm{NO}_{3}{ }^{-}$, respectively. When making the headspaces for $\mathrm{CH}_{4}$ measurements as described above, the excess water was collected and used to quantify the evolution of $\mathrm{NO}_{3}{ }^{-}$concentrations in the incubations (reported as $\mathrm{NO}_{3}{ }^{-}$consumption rates), according to the method previously described.

Samples for sulfide $\left(\mathrm{HS}^{-}\right)$concentrations were collected in $50 \mathrm{ml}$ plastic vials, after being filtered on a $0.22 \mu \mathrm{m}$ syringe filter. Samples were preserved with $200 \mu 1$ of $20 \%$ zinc acetate ( $\mathrm{ZnAc}$ ) and were stored frozen. HS $^{-}$concentrations were quantified using a 5 -cm light path on a spectrophotometer, according to the method described by Cline (1969). Samples for $\mathrm{SO}_{4}{ }^{2-}$ analyses were filtered on a $0.22 \mu \mathrm{m}$ syringe filter and collected in 5 ml Cryotube vials. Samples were preserved with $20 \mu 1$ of $20 \% \mathrm{ZnAc}$ and were stored frozen. $\mathrm{SO}_{4}{ }^{2-}$ concentrations were determined by ion chromatography (Dionex ICS-1500, with an autosampler Dionex AS50, a guard column Dionex AG22 and an analytical column Dionex IonPac AS22). The detection limits of these methods were 0.25 and $0.5 \mu \mathrm{mol} \mathrm{L}^{-1}$ for $\mathrm{HS}^{-}$and $\mathrm{SO}_{4}{ }^{2-}$, respectively. In August 2014, the decrease of $\mathrm{SO}_{4}{ }^{2-}$ concentrations in $\mathrm{CH}_{4}$ incubations was measured by spectrophotometry, using a $5-\mathrm{cm}$ light path on a spectrophotometer Thermo 
Biogeosciences Discuss., doi:10.5194/bg-2016-300, 2016

Manuscript under review for journal Biogeosciences

Published: 21 July 2016

(c) Author(s) 2016. CC-BY 3.0 License.

Spectronic Genesys 10vis, according to the nephelometric method described by Rodier et al. (1996), after precipitation of barium sulfate in an acid environment. The detection limit of this method was $52 \mu \mathrm{mol} \mathrm{L}{ }^{-1}$.

In May 2013, September 2013 and August 2014, samples for Fe and Mn measurements were collected into $50 \mathrm{ml}$-plastic syringes directly from the Niskin bottle. Water was rapidly transferred from the syringe to the filtration set and was passed through $25 \mathrm{~mm}$ glass fiber filters. Filters were collected in $2 \mathrm{ml}$ Eppendorf vials and preserved with $1 \mathrm{ml}$ of a $\mathrm{HNO}_{3} 2 \%$ solution, while filtrates were collected into four $2 \mathrm{ml}$ Eppendorf vials and preserved with $20 \mu \mathrm{l}$ of a $\mathrm{HNO}_{3} 65 \%$ solution. The filters, for particulate $\mathrm{Fe}$ and $\mathrm{Mn}$ determination, were mineralized in specific Teflon bombs into a microwave digestion labstation (Ethos D, Milestone Inc.), after digestion with nitric acid. They were finally diluted into milli-Q water to the volume of $50 \mathrm{ml}$. Filtrates were directly diluted into milli-Q water to the volume of $50 \mathrm{ml}$. In August 2014, dissolved Mn and Fe concentrations were also determined in $\mathrm{CH}_{4}$ incubations in order to measure the evolution of concentrations through time. $\mathrm{Fe}$ and Mn concentrations were determined by inductively coupled plasma mass spectrometry (ICP-MS) using dynamic reaction cell (DRC) technology (ICP-MS SCIEX ELAN DRC II, PerkinElmer inc.). Analytical accuracy was verified by a certified reference material (BCR 715, Industrial Effluent Wastewater).

\section{4 $\mathrm{CH}_{4}$ oxidation, $\mathrm{NO}_{3}{ }^{-}$and $\mathrm{SO}_{4}{ }^{2-}$ consumption and $\mathrm{Mn}^{2+}$ production rates calculations}

$\mathrm{CH}_{4}$ oxidation, $\mathrm{NO}_{3}{ }^{-}$and $\mathrm{SO}_{4}{ }^{2-}$ consumption and $\mathrm{Mn}^{2+}$ production rates were calculated as a linear

regression of $\mathrm{CH}_{4}, \mathrm{NO}_{3}{ }^{-}, \mathrm{SO}_{4}{ }^{2-}$ and $\mathrm{Mn}^{2+}$ concentrations over time during the course of the incubation. Rates reported here are maximum rates, as they were calculated based on the maximum slopes. Table 1 shows standard deviations, initial $\mathrm{CH}_{4}$ concentrations, percentage of $\mathrm{CH}_{4}$ consumed and the time laps during which the $\mathrm{CH}_{4}$ oxidation rates were calculated for each depth. Table 2 shows standards deviations for $\mathrm{NO}_{3}{ }^{-}$and $\mathrm{SO}_{4}{ }^{2-}$ consumption and $\mathrm{Mn}^{2+}$ production rates.

$\mathrm{CH}_{4}$ oxidation rates with molybdate were corrected taking into account the oxygen supplied by the addition of the solution, which was not anoxic. As molybdate solution was at saturation with respect to $\mathrm{O}_{2}$, we considered here that $1.25 \mu \mathrm{mol} \mathrm{L}^{-1}$ of $\mathrm{O}_{2}$ were added to each bottle $(250 \mu \mathrm{l}$ of the solution were added to $60 \mathrm{ml}$ of water). The $\mathrm{O}_{2}$ concentration required to be responsible for each $\mathrm{CH}_{4}$ oxidation rate was calculated according to the following stoichiometric equation Eq. (1):

The part of each oxidation rate due to $\mathrm{O}_{2}$ was then calculated according to Eq. (2):

$$
\text { (2) } R o=\frac{R m}{O 2 r} * 02 a
$$

where Ro is the part of each oxidation rate due to $\mathrm{O}_{2}$ supply, $\mathrm{Rm}$ is the measured oxidation rate, $\mathrm{O} 2 \mathrm{r}$ is the $\mathrm{O}_{2}$ concentration required to be responsible for the measured $\mathrm{CH}_{4}$ oxidation rate and $\mathrm{O} 2 \mathrm{a}$ is the $\mathrm{O}_{2}$ concentration added by the molybdate solution.

The final $\mathrm{CH}_{4}$ oxidation rates with molybdate were obtained by subtraction (Eq. 3):

(3) Final $\mathrm{CH}_{4}$ oxidation rate with $\mathrm{Mo}=\mathrm{Rm}-\mathrm{Ro}$ 
Biogeosciences Discuss., doi:10.5194/bg-2016-300, 2016

Manuscript under review for journal Biogeosciences

Published: 21 July 2016

(c) Author(s) 2016. CC-BY 3.0 License.

All rates with molybdate reported here are final $\mathrm{CH}_{4}$ oxidation rates.

\subsection{N stable isotope labelling experiments}

145 denitrification was determined by the injection of a $\mathrm{Na}^{15} \mathrm{NO}_{3}$ solution in amber bottles, through the stopper (final concentration of $5 \mu \mathrm{mol} \mathrm{L}^{-1}$ ). Six $12 \mathrm{ml}$ vials (Labco Exetainer) were then filled from each of the duplicate bottles and placed in the dark in an incubator at ambient temperature $\left(24^{\circ} \mathrm{C}\right)$, which was close to the in situ temperature $\left(\sim 23^{\circ} \mathrm{C}\right)$. Microbial activity in two Exetainers was immediately arrested through the addition of $500 \mu 120 \% \mathrm{ZnAc}$.

A time course was established by arresting two further Exetainers at 6, 12, 18, 24 and $48 \mathrm{~h}$. While injecting ZnAc solution to stop the incubations of the Exetainers, the excess water was collected in 2 ml-Eppendorf vials, and stored frozen, to determine the evolution of the $\mathrm{NO}_{x}{ }^{-}$concentrations through time. $\mathrm{NO}_{\mathrm{x}}{ }^{-}$were then analyzed by chemiluminescence, after reduction with vanadium chloride $\left(\mathrm{VCl}_{3}\right)$, with an $\mathrm{NO}_{2}{ }^{-}, \mathrm{NO}_{3}{ }^{-}$and $\mathrm{NO}_{\mathrm{x}}$ analyzer (Thermo Environmental Instruments), according to the method described by Braman and Hendrix (1989) (detection limit: 2-3 ng $\mathrm{NO}_{\mathrm{x}}$ ).

${ }^{29} \mathrm{~N}_{2}$ and ${ }^{30} \mathrm{~N}_{2}$ concentrations in the Exetainers were measured with a gas source isotope ratio mass spectrometer (Delta V Plus, ThermoScientific) after creating a $2 \mathrm{ml}$ helium headspace (volume injected in the mass spectrometer: $50 \mu \mathrm{l}$ ). Potential denitrification rates (detection limits of $2.7 \mathrm{nmol} \mathrm{L}^{-1} \mathrm{~h}^{-1}$ ) in the incubations with ${ }^{15} \mathrm{NO}_{3}{ }^{-}$were calculated according to Eq. (4) (Thamdrup and Dalsgaard, 2002):

(4) Potential $\mathrm{N}_{2}$ denitrification $={ }^{15} \mathrm{~N}^{15} \mathrm{~N}_{\text {excess }} *\left(\mathrm{~F}_{\mathrm{NO} 3}\right)^{-2}$

where $\mathrm{N}_{2}$ denitrification is the production of $\mathrm{N}_{2}$ by denitrification during the incubations with ${ }^{15} \mathrm{NO}_{3} \cdot{ }^{-15} \mathrm{~N}^{15} \mathrm{~N}_{\text {excess }}$ is the production of excess ${ }^{15} \mathrm{~N}^{15} \mathrm{~N}$ and $\mathrm{F}_{\mathrm{NO} 3}$ is the fraction of ${ }^{15} \mathrm{NO}_{3}{ }^{-}$added in the $\mathrm{NO}_{\mathrm{x}}{ }^{-}$pool. $\mathrm{NO}_{\mathrm{x}}{ }^{-}$concentrations of the $\mathrm{NO}_{\mathrm{x}}$. pool were measured in the incubations as described above. ${ }^{15} \mathrm{~N}^{15} \mathrm{~N}$ is the excess relative to the mass 30: mass 28 ratio in the time zero gas samples.

Only natural denitrification rates are reported here. Natural denitrification rates were calculated on the base on potential denitrification rates, according to Eq. (5):

(5) Natural $\mathrm{N}_{2}$ denitrification $=$ Potential $\mathrm{N}_{2}$ denitrification $*\left(1-\mathrm{F}_{\mathrm{NO} 3}\right)$, which assumes that the rate obeys $1^{\text {st }}$ order kinetics with respect to $\mathrm{NO}_{3}^{-}$. 
Biogeosciences Discuss., doi:10.5194/bg-2016-300, 2016

Manuscript under review for journal Biogeosciences

Published: 21 July 2016

(c) Author(s) 2016. CC-BY 3.0 License.

\section{Results}

\subsection{Physico-chemical characteristics of the water column}

Vertical profiles of physico-chemical variables differed strongly between stations and campaigns (Fig. 2). In the dry season, the water column was anoxic from 47.5, 57.5, 55 and $60 \mathrm{~m}$ in June 2011, October 2012, September 2013 and August 2014, respectively. In the rainy season, it was anoxic from 45 and 55 m in February 2012 and May 2013, respectively. At each date, the thermocline mirrored the oxycline and temperature at the oxicanoxic interface averaged $23.5 \pm 0.2^{\circ} \mathrm{C}$ (mean \pm standard deviation). The chemocline (based on conductivity and $\mathrm{pH}$ ) was relatively stable and started at $\sim 50 \mathrm{~m}$.

$\mathrm{CH}_{4}$ concentrations were low $\left(0.3 \pm 0.5 \mu \mathrm{mol} \mathrm{L}^{-1}\right)$ from the surface to $45-55 \mathrm{~m}$ where they started to increase; at $70 \mathrm{~m}, \mathrm{CH}_{4}$ concentrations were $385 \pm 43 \mu \mathrm{mol} \mathrm{L}^{-1}$ (Fig. 3). For all campaigns, $\mathrm{N}_{2} \mathrm{O}$ concentrations were higher in oxic waters $\left(7.0 \pm 0.4 \mathrm{nmol} \mathrm{L}^{-1}\right.$ from $\left.0-40 \mathrm{~m}\right)$ than in anoxic waters $\left(1.3 \pm 0.8 \mathrm{nmol} \mathrm{L}^{-1}\right.$ below $60 \mathrm{~m}$ depth). In February 2012 and September 2013, peaks of $\mathrm{N}_{2} \mathrm{O}$ up to $15 \mathrm{nmol} \mathrm{L}^{-1}$ were observed at $50 \mathrm{~m}$ (anoxic waters) and at $45 \mathrm{~m}$ (oxic waters), respectively.

$\mathrm{NO}_{\mathrm{x}}$ profiles also reflected the seasonal variations of the water column characteristics. A zone of $\mathrm{NO}_{\mathrm{x}}$ accumulation (nitracline) was not observed in June 2011 and May 2013, and a small one $\left(<2 \mu \mathrm{mol} \mathrm{L}^{-1}\right.$ at $\left.52.5 \mathrm{~m}\right)$ was observed in August 2014. In February 2012, October 2012 and September 2013, $\mathrm{NO}_{\mathrm{x}}$ maxima of $3 \mu \mathrm{mol} \mathrm{L}{ }^{-1}$ (at $50 \mathrm{~m}$ ), $4 \mu \mathrm{mol} \mathrm{L}^{-1}$ (at $50 \mathrm{~m}$ ) and $4 \mu \mathrm{mol} \mathrm{L}^{-1}$ (at $47.5 \mathrm{~m}$ ), respectively, were observed. For all campaigns, $\mathrm{NH}_{4}{ }^{+}$ concentrations were low $\left(<1 \mu \mathrm{mol} \mathrm{L}^{-1}\right)$ in oxic waters, and increased in anoxic waters $\left(82 \pm 59 \mu \mathrm{mol} \mathrm{L}^{-1}\right.$ at $\left.70 \mathrm{~m}\right)$. $\mathrm{SO}_{4}{ }^{2-}$ and $\mathrm{H}_{2} \mathrm{~S}$ concentrations did not show high fluctuations between the different campaigns, with means of 153 $\pm 21 \mu \mathrm{mol} \mathrm{L}{ }^{-1}$ in oxic waters (from 0 to $50 \mathrm{~m}$ depth) and $42 \pm 25 \mu \mathrm{mol} \mathrm{L} \mathrm{L}^{-1}$ in anoxic waters (at $70 \mathrm{~m}$ depth), respectively. $\mathrm{SO}_{4}{ }^{2-}$ concentrations strongly decreased at the oxic-anoxic interface (until $\sim 0 \mu \mathrm{mol} \mathrm{L}{ }^{-1}$ at $80 \mathrm{~m}$ depth), while HS- ${ }^{-}$concentrations increased.

Fe concentrations were very low (less than $2 \mu \mathrm{mol} \mathrm{L^{-1 }}$ all along the vertical profiles, not shown). Particulate Mn concentrations were low (less than $2 \mu \mathrm{mol} \mathrm{L}^{-1}$ ), with a maximum concentration peak located just above the oxic-anoxic interface, for the three campaigns. Dissolved Mn concentrations increased with depth, until maximum concentrations of $10 \mu \mathrm{mol} \mathrm{L}^{-1}$ in anoxic waters.

\subsection{Microbial process rate measurements}

$\mathrm{CH}_{4}$ oxidation was detected during all field campaigns (Fig. 4). Aerobic $\mathrm{CH}_{4}$ oxidation rates tended to be faster than anaerobic ones, since aerobic $\mathrm{CH}_{4}$ oxidation consumed on average $0.9 \%$ of initial $\mathrm{CH}_{4}$ per hour, while anaerobic $\mathrm{CH}_{4}$ oxidation consumed $0.2 \%$ of initial $\mathrm{CH}_{4}$ per hour. With molybdate added, $0.2 \%$ of initial $\mathrm{CH}_{4}$ concentrations were also consumed per hour on average.

The dry season was characterized by higher maximum $\mathrm{CH}_{4}$ oxidation rates in oxic waters compared to anoxic waters. The maximum oxic and anoxic oxidation rates were observed in August 2014 and were $27 \pm 2$ (at $55 \mathrm{~m}$ ) and $16 \pm 8$ (at $75 \mathrm{~m}) \mu \mathrm{mol} \mathrm{L^{-1 }} \mathrm{d}^{-1}$, respectively. This high anoxic rate was accompanied by a high $\mathrm{SO}_{4}{ }^{2-}$ consumption rate of $18 \pm 6 \mu \mathrm{mol} \mathrm{L} \mathrm{L}^{-1} \mathrm{~d}^{-1}$ observed at $70 \mathrm{~m}$ depth. $\mathrm{CH}_{4}$ oxidation rates, especially those located in anoxic waters, were lower during the other field campaigns, but were detectable and non-negligible. Maximum 
Biogeosciences Discuss., doi:10.5194/bg-2016-300, 2016

Manuscript under review for journal Biogeosciences

Published: 21 July 2016

(c) Author(s) 2016. CC-BY 3.0 License.

oxic $\mathrm{CH}_{4}$ oxidation rates were $2 \pm 0.04$ and $13.9 \pm 0.0 \mu \mathrm{mol} \mathrm{L}^{-1} \mathrm{~d}^{-1}$, while maximum anoxic rates were $0.8 \pm 0.01$ (at $47.5 \mathrm{~m}$ ) and $3.5 \pm 0.3$ (at $65 \mathrm{~m}$ ) $\mu \mathrm{mol} \mathrm{L}^{-1} \mathrm{~d}^{-1}$, in June 2011 and September 2013, respectively. In October 2012, no $\mathrm{CH}_{4}$ oxidation rate was observed in anoxic water, but a high rate of $10.2 \pm 0.4 \mu \mathrm{mol} \mathrm{L}^{-1} \mathrm{~d}^{-1}$ was observed in oxic waters. $\mathrm{NO}_{3}{ }^{-}$consumption rates tended to be low during all the campaigns, but a non-negligible natural

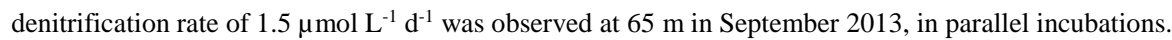

During the rainy season, maximum $\mathrm{CH}_{4}$ oxidation rates in anoxic waters were higher than in oxic waters. In February 2012, the maximum anoxic $\mathrm{CH}_{4}$ oxidation rate of $7.7 \pm 0.4 \mu \mathrm{mol} \mathrm{L}^{-1} \mathrm{~d}^{-1}$ was observed at $50 \mathrm{~m}$ and cooccurred with the maximum $\mathrm{NO}_{3}{ }^{-}$consumption rate of $0.4 \pm 0.1 \mu \mathrm{mol} \mathrm{L}^{-1} \mathrm{~d}^{-1}$. In May 2013, the maximum anoxic

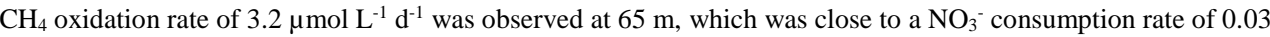
$\pm 0.01 \mu \mathrm{mol} \mathrm{L} \mathrm{L}^{-1} \mathrm{~d}^{-1}$ observed at $70 \mathrm{~m}$ depth. Also, higher rates of natural denitrification (based on ${ }^{15} \mathrm{~N}$ ) were observed between 60 and $70 \mathrm{~m}$ depth, with a maximum of $0.7 \mu \mathrm{mol} \mathrm{NO}{ }_{3}^{-} \mathrm{L}^{-1} \mathrm{~d}^{-1}$ at $60 \mathrm{~m}$ depth. No oxic $\mathrm{CH}_{4}$ oxidation rate was observed in February 2012, while a maximum rate of $1.5 \pm 0.2 \mu \mathrm{mol} \mathrm{L}^{-1} \mathrm{~d}^{-1}$ was observed in May 2013.

In February 2012 and August 2014, $\mathrm{CH}_{4}$ oxidation rates decreased when molybdate was added, while rates tended to increase when molybdate was added during the other field campaigns. In October 2012 and May 2013 in particular, $\mathrm{CH}_{4}$ oxidation rates strongly increased when molybdate was added, from $0 \pm 0$ to $23 \pm 0.4$ $\mu \mathrm{mol} \mathrm{L} \mathrm{L}^{-1} \mathrm{~d}^{-1}$ (at $80 \mathrm{~m}$ ) and from 3 to $18 \mu \mathrm{mol} \mathrm{L}^{-1} \mathrm{~d}^{-1}$ (at $65 \mathrm{~m}$ ), respectively. In September 2013, $\mathrm{CH}_{4}$ oxidation rates increased when molybdate was added up to $11 \pm 0.5 \mu \mathrm{mol} \mathrm{L}^{-1} \mathrm{~d}^{-1}$ at $55 \mathrm{~m}$. In August 2014, the addition of molybdate was also accompanied by a strong increase of dissolved $\mathrm{Mn}\left(\mathrm{Mn}^{2-}\right)$ production rates. $\mathrm{NO}_{3}{ }^{-}$consumption rates also tended to increase when molybdate was added during all field campaigns.

\section{Discussion}

High $\mathrm{CH}_{4}$ oxidation rates were observed in oxic and anoxic waters (maximum $27 \pm 2$ and $16 \pm 8 \mu \mathrm{mol} \mathrm{L}$ ${ }^{1} \mathrm{~d}^{-1}$, respectively). Aerobic $\mathrm{CH}_{4}$ oxidation rates were sometimes very high when considering the initial $\mathrm{CH}_{4}$ concentrations (Table 1). For example, the maximum aerobic $\mathrm{CH}_{4}$ oxidation rate of $27 \pm 2 \mu \mathrm{mol} \mathrm{L}^{-1} \mathrm{~d}^{-1}$ observed at $55 \mathrm{~m}$ depth in August 2014 occurred at $\mathrm{CH}_{4}$ concentrations of $42 \pm 2 \mu \mathrm{mol} \mathrm{L} \mathrm{L}^{-1}$. However, as shown in Table 1 , this rate applied on a period of $24 \mathrm{~h}$, and $68 \%$ of the initial $\mathrm{CH}_{4}$ was consumed after $24 \mathrm{~h}$. The same observation is made, for example, in June 2011 (at 42.5 and 45 m), February 2012 (at 50 m) and October 2012 (at 53 m).

A great variability in oxidation rates was observed between the different campaigns. The main pathway of $\mathrm{CH}_{4}$ oxidation was aerobic in June 2011, October 2012 and September 2013 (dry season) and anaerobic in February 2012 and May 2013 (rainy season) (Table 3). In August 2014, aerobic and anaerobic oxidation rates were quite equivalent. As shown by Figure 5, aerobic oxidation rates tended to depend on the oxygenated layer depth. Aerobic $\mathrm{CH}_{4}$ oxidation rates tended to be higher when the mixed surface water was deeper, as usually observed in dry season. This observation confirms hypothesis by Roland et al. (2016a) who suggested, based on the seasonal evolution with depth of $\mathrm{CH}_{4}$ concentrations, that during the dry season, the oxic layer deepens and integrated aerobic $\mathrm{CH}_{4}$ oxidation on the oxic water column is higher. On the contrary, during the rainy season, the oxic layer is thinner, and a greater amount of $\mathrm{CH}_{4}$ can be anaerobically oxidized before reaching the oxic part of the water column. While aerobic $\mathrm{CH}_{4}$ oxidation is probably limited by $\mathrm{CH}_{4}$ concentrations, $\mathrm{AOM}$ is probably limited by the availability of electron acceptors due to competition with more favorable processes (such as heterotrophic 
Biogeosciences Discuss., doi:10.5194/bg-2016-300, 2016

Manuscript under review for journal Biogeosciences

Published: 21 July 2016

(c) Author(s) 2016. CC-BY 3.0 License.

denitrification, sulfate reduction etc.). Also episodic fluctuations in water column characteristics influence bacterial communities and small variations in the water column structure may influence the abundance and/or distribution of bacterial communities, and thus contribute to differences observed. Anyway, the relatively high aerobic and anaerobic $\mathrm{CH}_{4}$ oxidation rates measured during this study and estimated from ${ }^{13} \mathrm{C}-\mathrm{CH}_{4}$ production by Morana et al. (2015a) explain the low $\mathrm{CH}_{4}$ fluxes observed throughout the year in Lake Kivu (Borges et al., 2011;Roland et al., 2016a).

Aerobic and anaerobic $\mathrm{CH}_{4}$ oxidation rates are also high compared with most other lakes (Table 4). Large differences observed can be easily explained by the different characteristics of the environments, such as vertical structure of the water column, $\mathrm{CH}_{4}$ concentrations, $\mathrm{O}_{2}$ and other electron acceptors concentrations, or water temperature. Lake Kivu is a tropical lake, so high water temperatures enhance bacterial activity, contrary to temperate and boreal lakes. Also, the water column of Lake Kivu allows the accumulation of high $\mathrm{CH}_{4}$ concentrations in anoxic waters, which can slowly diffuse to the oxic compartment, allowing the occurrence of both aerobic and anaerobic $\mathrm{CH}_{4}$ oxidation. Very high AOM rates observed in Lake Matano compared with Lake Kivu may be explained by higher $\mathrm{CH}_{4}$ concentrations in anoxic waters and greater concentrations of the highly favorable electron acceptor Fe (Sturm et al., 2016).

Different depth profile patterns were observed when molybdate, the inhibitor of sulfate-reducing bacteria activity, was added. About half of the measurements gave lower rates with molybdate added, and the other half gave higher rates (Fig. 6). In February 2012 and August 2014, AOM rates were lower with molybdate, suggesting the occurrence of $\mathrm{AOM}$ coupled with $\mathrm{SO}_{4}{ }^{2-}$ reduction. Measurement of the $\mathrm{SO}_{4}{ }^{2-}$ consumption rate during the incubations were performed in August 2014. The highest rate of $\mathrm{SO}_{4}{ }^{2-}$ consumption $\left(18 \pm 6 \mu \mathrm{mol} \mathrm{L}^{-1} \mathrm{~d}^{-1}\right)$ was observed at $70 \mathrm{~m}$, what was close to the higher AOM peak of $16 \pm 8 \mu \mathrm{mol} \mathrm{L}^{-1} \mathrm{~d}^{-1}$ observed at $75 \mathrm{~m}$ depth. In terms of stoichiometry, Fig. 7a shows that one AOM peak can be easily explained by the $\mathrm{SO}_{4}{ }^{2-}$ reduction rate, since 1 mole of $\mathrm{SO}_{4}{ }^{2-}$ is needed to oxidize 1 mole of $\mathrm{CH}_{4}$, according to Eq. (6):

$$
\text { (6) } \mathrm{CH}_{4}+\mathrm{SO}_{4}{ }^{2-} \rightarrow \mathrm{HCO}_{3}{ }^{-}+\mathrm{HS}^{-}+\mathrm{H}_{2} \mathrm{O}
$$

$\mathrm{SO}_{4}{ }^{2-}$ consumption rates were calculated from the change in time of $\mathrm{SO}_{4}{ }^{2-}$ concentrations measured with the nephelometric method, which might not be precise enough, since the detection limit was $52 \mu \mathrm{mol} \mathrm{L^{-1 }}$. Vertical

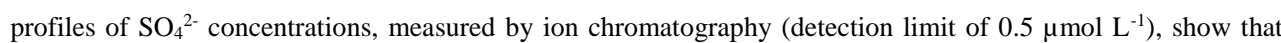
$\mathrm{SO}_{4}{ }^{2-}$ is present in enough quantity to explain AOM rates observed, for all campaigns (Table 5).

In February 2012, the maximum AOM peak of $7.7 \pm 0.4 \mu \mathrm{mol} \mathrm{L}^{-1} \mathrm{~d}^{-1}$ co-occurred with the maximum $\mathrm{NO}_{3}$ consumption peak of $0.4 \pm 0.1 \mu \mathrm{mol} \mathrm{L}^{-1} \mathrm{~d}^{-1}$, at $50 \mathrm{~m}$ depth, suggesting that a part of AOM might have been due to $\mathrm{NO}_{3}{ }^{-}$reduction. $\mathrm{NO}_{3}{ }^{-}$consumption rates do not clearly determine if denitrification occurs in Lake Kivu, since the $\mathrm{NO}_{3}{ }^{-}$consumption recorded during the incubations might reflect the incorporation of $\mathrm{N}$ into the biomass, or reduction to ammonium. However, in a companion paper, we showed that natural denitrification occurred in the Northern Basin in 2011 and 2012, at rates ranging between 1.2 and $2232 \mathrm{nmol} \mathrm{NO}_{3}^{-} \mathrm{L}^{-1} \mathrm{~d}^{-1}$, during the same field campaigns, at depths close to those where we observed AOM rates (Roland et al., 2016b). Moreover, in May and September 2013, we also observed natural denitrification rates in parallel incubations, and higher denitrification rates co-occurred with higher $\mathrm{AOM}$ rates. Fig. $7 \mathrm{~b}$ and $7 \mathrm{c}$ show $\mathrm{AOM}$ rates calculated based on the $\mathrm{NO}_{3}$ consumption rates measured in the incubations and based on natural denitrification rates measured in parallel 
Biogeosciences Discuss., doi:10.5194/bg-2016-300, 2016

Manuscript under review for journal Biogeosciences

Published: 21 July 2016

(c) Author(s) 2016. CC-BY 3.0 License.

incubations (only in May and September 2013), respectively, and according to the stoichiometry of Eq. (7), where 8 moles of $\mathrm{NO}_{3}{ }^{-}$are needed for 5 moles of $\mathrm{CH}_{4}$ (Raghoebarsing et al., 2006):

(7) $5 \mathrm{CH}_{4}+8 \mathrm{NO}_{3}{ }^{-}+8 \mathrm{H}^{+} \rightarrow 5 \mathrm{CO}_{2}+4 \mathrm{~N}_{2}+14 \mathrm{H}_{2} \mathrm{O}$

All AOM rates cannot be solely explained by $\mathrm{NO}_{3}{ }^{-}$consumption rates. Even natural denitrification rates are not sufficient to explain AOM rates observed. This discrepancy suggests that $\mathrm{NO}_{3}{ }^{-}$is not an important electron acceptor for AOM in Lake Kivu, which is not surprising when considering low natural $\mathrm{NO}_{3}{ }^{-}$concentrations. Indeed, the majority of AOM rates observed cannot be explained by the $\mathrm{NO}_{\mathrm{x}}$ concentrations (Table 3). Only very low AOM rates can be fully explained by $\mathrm{NO}_{x}$ concentrations. $\mathrm{MnO}_{2}$ and $\mathrm{Mn}^{2+}$ concentrations were also measured in May 2013, September 2013 and August 2014 (Fig. 3). AOM can occur with $\mathrm{MnO}_{2}$ as electron acceptor, and produce $\mathrm{Mn}^{2+}$ according to Eq. (8) (Beal et al., 2009):

(8) $\mathrm{CH}_{4}+4 \mathrm{MnO}_{2}+7 \mathrm{H}^{+} \rightarrow \mathrm{HCO}_{3}{ }^{-}+4 \mathrm{Mn}^{2+}+5 \mathrm{H}_{2} \mathrm{O}$

According to this relationship, 1 mole of $\mathrm{CH}_{4}$ consumes 4 moles of $\mathrm{MnO}_{2}$ and produces 4 moles of $\mathrm{Mn}^{2+}$. In May 2013 and September 2013, we can see that $\mathrm{MnO}_{2}$ can fully contribute to $\mathrm{AOM}$ at depths near the oxicanoxic interface (Table 5). At $65 \mathrm{~m}$ in May 2013, we can see that $\mathrm{MnO}_{2}$ can only contribute for $45 \%$ of $\mathrm{AOM}$ rate. Particulate Mn concentrations were very low compared with dissolved Mn concentrations, with a peak located just above the oxic-anoxic interface, for each campaign. Jones et al. (2011) showed the same profile in Lake Matano, and concluded that $\mathrm{Mn}$ is recycled at least 15 times before sedimentation. $\mathrm{Mn}^{2+}$ is probably oxidized in presence of small quantities of $\mathrm{O}_{2}$, precipitates and is directly reduced in anoxic waters. The same profile is probably observed in Lake Kivu, and $\mathrm{MnO}_{2}$ can thus probably significantly contributes to AOM only at depths close to the oxic-anoxic interface. A significant part of AOM could be due to $\mathrm{MnO}_{2}$ reduction for each depth if we take into account $\mathrm{Mn}^{2+}$ concentrations (Table 5), and considering two hypotheses: 1) All the $\mathrm{Mn}^{2+}$ measured at each depth come from the reduction of precipitated $\mathrm{MnO}_{2}$, and 2) all the $\mathrm{Mn}^{2+}$ come from $\mathrm{MnO}_{2}$ reduction with $\mathrm{CH}_{4}$. However, these hypotheses are unlikely, since $\mathrm{Mn}^{2+}$ present at each depth can come from diffusion from upper depths, and $\mathrm{MnO}_{2}$ can be reduced by other electron donors than $\mathrm{CH}_{4}$. Also, for $\mathrm{SO}_{4}{ }^{2-}$ and $\mathrm{NO}_{\mathrm{x}}$, other processes such as $\mathrm{SO}_{4}{ }^{2-}$ reduction with organic matter and heterotrophic denitrification can take place. The percentages of AOM reported in Table 5 and the calculated AOM rates reported in Fig. 7 are thus potential maximum percentages and rates. Nevertheless, $\mathrm{CH}_{4}$ has the potential to be the major electron donor in anoxic waters of Lake Kivu based on consideration of the standing stocks and fluxes of carbon. Indeed, $\mathrm{CH}_{4}$ concentration at $70 \mathrm{~m}$ is $\sim 385 \mu \mathrm{mol} \mathrm{L}{ }^{-1}$ which is distinctly higher than typical dissolved organic carbon concentrations of $142 \mu \mathrm{mol} \mathrm{L}^{-1}$ that is very refractory anyway (Morana et al., 2014; 2015b) and particulate organic carbon (POC) concentrations in anoxic waters typically lower than $30 \mu \mathrm{mol} \mathrm{L}^{-1}$ (Morana et al., 2015b). In terms of supply of carbon, the $\mathrm{CH}_{4}$ vertical flux of $9.4 \mathrm{mmol} \mathrm{m}^{-2} \mathrm{~d}^{-1}$ (Morana et al., 2015a) is also higher compared to the downward flux of POC from the mixed layer of $5.2 \pm 1.7 \mathrm{mmol} \mathrm{m}^{-2} \mathrm{~d}^{-1}$ (average value of 24 month-deployment of sediment traps in the Northern Basin from November 2012 to November 2014, unpublished data). This is in general agreement with the high methanotrophic production in Lake Kivu $\left(8.2-28.6 \mathrm{mmol} \mathrm{m}^{-2} \mathrm{~d}^{-1}\right)$ estimated by parallel study (Morana et al., 2015a).

Considering very high $\mathrm{SO}_{4}{ }^{2-}$ concentrations compared with other potential electron acceptors (mean of 103, 0.40 and $0.42 \mu \mathrm{mol} \mathrm{L}{ }^{-1}$ for $\mathrm{SO}_{4}{ }^{2-}, \mathrm{NO}_{\mathrm{x}}$ and particulate $\mathrm{Mn}$, respectively, at depths where $\mathrm{AOM}$ was observed), it 
Biogeosciences Discuss., doi:10.5194/bg-2016-300, 2016

Manuscript under review for journal Biogeosciences

Published: 21 July 2016

(c) Author(s) 2016. CC-BY 3.0 License.

is likely that AOM in Lake Kivu is mainly coupled to $\mathrm{SO}_{4}{ }^{2-}$ reduction. Moreover, half of the measurements showed that the inhibition of SRB activity by molybdate induced a decrease of AOM rates. However, the other half of the measurements showed that AOM rates were higher when molybdate was added. These results were surprising and difficult to explain. We firstly considered if we artificially induced aerobic oxidation by injecting molybdate, since the solution was not anoxic. As described in Sect. 2.4, we calculated the impact of $\mathrm{O}_{2}$ supply for each $\mathrm{CH}_{4}$ oxidation rate, which was clearly limited, since the median value of relative standard deviations (between rates with molybdate and rates with molybdate if no $\mathrm{O}_{2}$ was added) was $2.5 \%$, and thus did not strongly influence $\mathrm{CH}_{4}$ oxidation rates. Even if a significant artificially-induced aerobic oxidation can be ruled out, the $\mathrm{O}_{2}$ supply could potentially induce $\mathrm{NO}_{3}{ }^{-}$and $\mathrm{SO}_{4}{ }^{2-}$ production, and thus increase $\mathrm{AOM}$ linked to these electron acceptors. However, no increased $\mathrm{NO}_{3}{ }^{-}$production was observed during the incubations with molybdate (data not shown). We were not able to directly measure the $\mathrm{SO}_{4}{ }^{2-}$ concentrations in incubations with molybdate with the nephelometric method, due to a reaction between molybdate and reagents inducing absorbance higher than the maximum absorbance measurable for the specific wavelength. Since HS- oxidation is very fast (Canfield et al., 2005), it is very likely that the artificially introduced $\mathrm{O}_{2}$ was directly consumed by this way, and thus that $\mathrm{SO}_{4}{ }^{2-}$ concentrations were higher in incubations with molybdate. However, the increase of AOM in presence of molybdate was always

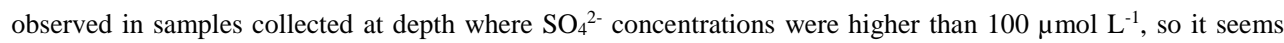

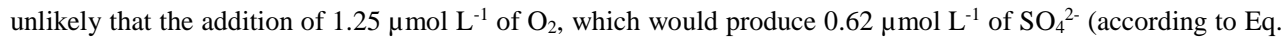
(9); Lens, 2009) could be responsible for a significant increase of AOM rates, in a context where $\mathrm{SO}_{4}{ }^{2-}$ were not limiting.

(9) $\mathrm{H}_{2} \mathrm{~S}+2 \mathrm{O}_{2} \rightarrow \mathrm{SO}_{4}{ }^{2-}+2 \mathrm{H}^{+}$

We can thus hypothesize that a modification in competitive relationships among the bacterial community in presence of molybdate, such as a decrease of competition between denitrifying bacteria and/or Mn-reducing bacteria and $\mathrm{SRB}$, would explain the higher $\mathrm{NO}_{3}{ }^{-}$consumption rates observed with molybdate added. Also, $\mathrm{Mn}^{2+}$ production rates increased with molybdate in August 2014. Competitive relationships for electron donors among bacterial communities have already been observed in literature (e.g. Westermann and Ahring, 1987, Achtnich et al., 1995). However, in Lake Kivu, it is unlikely that the strong increase in AOM rates was only due to a change in competition between SRB and denitrifying bacteria and/or SRB and Mn-reducing bacteria, since $\mathrm{NO}_{3}{ }^{-}$and $\mathrm{MnO}_{2}$ concentrations are in any way insufficient to be responsible for all AOM rates.

In conclusion, we put in evidence and measured AOM in the water column of a meromictic tropical lake. We were not able to clearly identify the main electron acceptor of AOM based on this dataset, but considering the high $\mathrm{SO}_{4}{ }^{2-}$ concentrations, it is likely that $\mathrm{AOM}$ could be mainly coupled to $\mathrm{SO}_{4}{ }^{2-}$ reduction. A seasonal variability in the respective importance of aerobic and anaerobic $\mathrm{CH}_{4}$ oxidation rates was observed, with a higher importance of aerobic oxidation in dry season and of AOM in rainy season. This can be linked to the position of the oxygenated layer depth, which is located deeper during the dry season, due to the seasonal mixing of the mixolimnion. At this period of the year, the oxic-anoxic interface is located close to the chemocline, below which the concentration of $\mathrm{CH}_{4}$ are typically 5 orders of magnitude larger than in the upper part of the mixolimnion. By contrast, during the rainy season, when the thermal stratification within the mixolimnion is well established, the volume of the oxic compartment is smaller than the volume of the anoxic compartment, and hence $\mathrm{CH}_{4}$ can only reach the oxic waters 
Biogeosciences Discuss., doi:10.5194/bg-2016-300, 2016

Manuscript under review for journal Biogeosciences

Published: 21 July 2016

(c) Author(s) 2016. CC-BY 3.0 License.

by diffusion, after that a significant fraction of the $\mathrm{CH}_{4}$ upward flux has been oxidized by $\mathrm{AOM}$, which limit the aerobic $\mathrm{CH}_{4}$ oxidation.

\section{Author contributions}

FAER, FD and AVB designed the experiments. FAER and AVB were responsible for manuscript preparation. FAER was also responsible for the fieldwork, the data acquisition, analysis and interpretation.

$\mathrm{CM}, \mathrm{FD}, \mathrm{SC}$ participated in fieldwork. CM, FD, SC and BT were involved in scientific discussions, data interpretation and manuscript preparation. SC was also involved in measurements of nutrients, sulfate and sulfide concentrations. BT also organized denitrification, nutrients, sulfate and sulfide measurements in the Institute of Biology and Nordic Center for Earth Evolution (University of Southern Denmark).

\section{Acknowledgements}

We thank the Rwanda Energy Company for the access to their platform for the sampling, Renzo Biondo (University of Liège), Laura Bristow, Dina Holmgaard Skov and Heidi Grøn Jensen (University of Southern Denmark) for help in measurements. This study was funded by the Belgian Federal Science Policy Office (BELSPO, Belgium) under the EAGLES (East African Great lake Ecosystem Sensitivity to Changes, SD/AR/02A) project, by the Fonds National de la Recherche Scientifique (FNRS) under the MICKI (Microbial diversity and processes in Lake Kivu, 1715859) project, and contributes to the European Research Council (ERC) starting grant project AFRIVAL (African river basins: Catchment-scale carbon fluxes and transformations, 240002). GC was acquired with funds from the FNRS (contract $n^{\circ}$ 2.4.598.07). AVB is a senior research associate at the FNRS FAER has a phD grant from FNRS («Fonds pour la formation à la Recherche dans l'Industrie et dans l'Agriculture »- FRIA). 
Biogeosciences Discuss., doi:10.5194/bg-2016-300, 2016

Manuscript under review for journal Biogeosciences

Published: 21 July 2016

(c) Author(s) 2016. CC-BY 3.0 License.

\section{References}

Achtnich, C., Bak, F., and Conrad, R.: Competition for electron donors among nitrate reducers, ferric iron reducers, sulfate reducers, and methanogens in anoxic paddy soil, Biol Fert Soils, 19, 65-72, doi:10.1007/BF00336349, 1995.

APHA: Standard methods for the examination of water and wastewater, edited by: APHA, Washington, 1998.

Bastviken, D., Ejlertsson, J., and Tranvik, L.: Measurement of methane oxidation in lakes: A comparison of methods, Environ. Sci. Technol., 36, 3354-3361, doi:10.1021/es010311p, 2002.

Bastviken, D., Tranvik, L. J., Downing, J. A., Crill, P. M., and Enrich-Prast, A.: Freshwater methane emissions offset the continental carbon sink, Science, 331, 50, doi:10.1126/science.1196808, 2011.

Beal, E. J., House, C. H., and Orphan, V. J.: Manganese-and iron-dependent marine methane oxidation, Science, 325, 184-187, doi:10.1126/science.1169984, 2009.

Boetius, A., Ravenschlag, K., Schubert, C. J., Rickert, D., Widdel, F., Gieseke, A., Amann, R., Jørgensen, B. B., Witte, U., and Pfannkuche, O.: A marine microbial consortium apparently mediating anaerobic oxidation of methane, Nature, 407, 623-626, doi:10.1038/35036572, 2000.

Borges, A. V., Abril, G., Delille, B., Descy, J. P., and Darchambeau, F.: Diffusive methane emissions to the atmosphere from Lake Kivu (Eastern Africa), J. Geophys. Res. Biogeosci., 116, doi:10.1029/2011JG001673, 2011.

Borges, A. V., Darchambeau, F., Teodoru, C. R., Marwick, T. R., Tamooh, F., Geeraert, N., Omengo, F. O., Guérin, F., Lambert, T., and Morana, C.: Globally significant greenhouse-gas emissions from African inland waters, Nat. Geosci., 8, 637, doi:10.1038/ngeo2486, 2015.

Borrel, G., Jézéquel, D., Biderre-Petit, C., Morel-Desrosiers, N., Morel, J.-P., Peyret, P., Fonty, G., and Lehours, A.-C.: Production and consumption of methane in freshwater lake ecosystems, Res. Microbiol., 162, 832847, doi:10.1016/j.resmic.2011.06.004, 2011.

Braman, R. S., and Hendrix, S. A.: Nanogram nitrite and nitrate determination in environmental and biological materials by vanadium(III) reduction with chemiluminescence detection, Anal. Chem., 61, 2715-2718, doi:10.1021/ac00199a007, 1989.

Canfield, D. E., Kristensen, E., and Thamdrup, B.: The sulfur cycle, Adv. Mar. Biol., 48, 313-381, doi:10.1016/S0065-2881(05)48009-8, 2005.

Cline, J. D.: Spectrophotometric determination of hydrogen sulfide in natural waters, Limnol. Oceanogr., 14, 454458, doi:10.4319/lo.1969.14.3.0454, 1969.

Conrad, R.: The global methane cycle: Recent advances in understanding the microbial processes involved, Environ. Microbiol. Rep., 1, 285-292, doi:10.1111/j.1758-2229.2009.00038.x, 2009.

Cui, M., Ma, A., Qi, H., Zhuang, X., and Zhuang, G.: Anaerobic oxidation of methane: an "active" microbial process, Microbiologyopen, 4, 1-11, doi:10.1002/mbo3.232, 2015.

İnceoğlu, Ö., Llirós, M., García-Armisen, T., Crowe, S. A., Michiels, C., Darchambeau, F., Descy, J.-P., and Servais, P.: Distribution of bacteria and archaea in meromictic tropical Lake Kivu (Africa), Aquat. Microb. Ecol., 74, 215-233, doi:10.3354/ame01737, 2015.

Iversen, N., and Jørgensen, B.: Anaerobic methane oxidation rates at the sulfate-methane transition in marine sediments from Kattegat and Skagerrak (Denmark), Limnol. Oceanogr., 30, 944-955, doi:10.4319/lo.1985.30.5.0944, 1985 .

Iversen, N., Oremland, R. S., and Klug, M. J.: Big Soda Lake (Nevada). 3. Pelagic methanogenesis and anaerobic methane oxidation, Limnol. Oceanogr., 32, 804-814, doi:10.4319/lo.1987.32.4.0804, 1987.

Jones, C., Crowe, S. A., Sturm, A., Leslie, K. L., MacLean, L. C. W., Katsev, S., Henny, C., Fowle, D. A., and Canfield, D. E.: Biogeochemistry of manganese in ferruginous Lake Matano, Indonesia, Biogeosciences, 8, 2977-2991, doi:10.5194/bg-8-2977-2011, 2011.

Jørgensen, B. B., Weber, A., and Zopfi, J.: Sulfate reduction and anaerobic methane oxidation in Black Sea sediments, Deep-Sea Res. Pt. I, 48, 2097-2120, doi:10.1016/S0967-0637(01)00007-3, 2001.

Kirschke, S., Bousquet, P., Ciais, P., Saunois, M., Canadell, J. G., Dlugokencky, E. J., Bergamaschi, P., Bergmann, D., Blake, D. R., Bruhwiler, L., Cameron-Smith, P., Castaldi, S., Chevallier, F., Feng, L., Fraser, A., Heimann, M., Hodson, E. L., Houweling, S., Josse, B., Fraser, P. J., Krummel, P. B., Lamarque, J. F., Langenfelds, R. L., Le Quéré, C., Naik, V., O'Doherty, S., Palmer, P. I., Pison, I., Plummer, D., Poulter, B., Prinn, R. G., Rigby, M., Ringeval, B., Santini, M., Schmidt, M., Shindell, D. T., Simpson, I. J., Spahni, R., Steele, L. P., Strode, S. A., Sudo, K., Szopa, S., Van Der Werf, G. R., Voulgarakis, A., Van Weele, M., Weiss, R. F., Williams, J. E., and Zeng, G.: Three decades of global methane sources and sinks, Nat. Geosci., 6, 813-823, doi:10.1038/ngeo1955, 2013.

Lens, P.: Sulfur cycle, in: Encyclopedia of microbiology, edited by: Schaechter, A., Elsevier, USA, 361-369, 2009.

Lopes, F., Viollier, E., Thiam, A., Michard, G., Abril, G., Groleau, A., Prévot, F., Carrias, J.-F., Albéric, P., and Jézéquel, D.: Biogeochemical modelling of anaerobic vs. aerobic methane oxidation in a meromictic 
Biogeosciences Discuss., doi:10.5194/bg-2016-300, 2016

Manuscript under review for journal Biogeosciences

Published: 21 July 2016

(c) Author(s) 2016. CC-BY 3.0 License.

crater lake (Lake Pavin, France), Appl. Geochem., 26, 1919-1932, doi:10.1016/j.apgeochem.2011.06.021, 2011.

Miranda, K. M., Espey, M. G., and Wink, D. A.: A rapid, simple spectrophotometric method for simultaneous detection of nitrate and nitrite, Nitric Oxide-Biol. Ch., 5, 62-71, doi:10.1006/niox.2000.0319, 2001.

Morana, C., Sarmento, H., Descy, J. P., Gasol, J. M., Borges, A. V., Bouillon, S., and Darchambeau, F.: Production of dissolved organic matter by phytoplankton and its uptake by heterotrophic prokaryotes in large tropical lakes, Limnol. Oceanogr., 59, 1364-1375, doi:10.4319/lo.2014.59.4.1364, 2014.

Morana, C., Borges, A. V., Roland, F. A. E., Darchambeau, F., Descy, J. P., and Bouillon, S.: Methanotrophy within the water column of a large meromictic tropical lake (Lake Kivu, East Africa), Biogeosciences, 12, 2077-2088, doi:10.5194/bg-12-2077-2015, 2015a.

Morana, C., Darchambeau, F., Roland, F. A. E., Borges, A. V., Muvundja, F. A., Kelemen, Z., Masilya, P., Descy, J. P., and Bouillon, S.: Biogeochemistry of a large and deep tropical lake (Lake Kivu, East Africa): insights from a stable isotope study covering an annual cycle, Biogeosciences, 12, 4953-4963, doi:10.5194/bg-12-4953-2015, 2015b.

Morana, C., Roland, F. A., Crowe, S. A., Llirós, M., Borges, A. V., Darchambeau, F., and Bouillon, S.: Chemoautotrophy and anoxygenic photosynthesis within the water column of a large meromictic tropical lake (Lake Kivu, East Africa), Limnol. Oceanogr., doi:10.1002/lno.10304, 2016.

Raghoebarsing, A. A., Pol, A., Van de Pas-Schoonen, K. T., Smolders, A. J., Ettwig, K. F., Rijpstra, W. I. C., Schouten, S., Damsté, J. S. S., den Camp, H. J. O., and Jetten, M. S.: A microbial consortium couples anaerobic methane oxidation to denitrification, Nature, 440, 918-921, doi:10.1038/nature04617, 2006.

Rodier, J., Bazin, C., Broutin, J., Chambon, P., Champsaur, H., and Rodi, L.: L'Analyse de l'Eau (8ème édn), Dunod, Paris: France, 1996.

Roland, F. A. E., Darchambeau, F., Morana, C., and Borges, A. V.: Nitrous oxide and methane seasonal variability in the epilimnion of a large tropical meromictic lake (Lake Kivu, East-Africa), Aquat. Sci., 1-10, doi:10.1007/s00027-016-0491-2, 2016a.

Roland, F. A. E., Crowe, S., Borges, A. V., De Brabandere, L., Morana, C., Servais, P., Thamdrup, B., and Darchambeau, F.: Denitrification, anaerobic ammonium oxidation and dissimilatory nitrate reduction to ammonium in an East African Great Lake (Lake Kivu), Limnol. Oceanogr., (in prep), 2016b.

Rudd, J. W.: Methane oxidation in Lake Tanganyika (East Africa), Limnol. Oceanogr., 25, 958-963, doi:10.4319/lo.1980.25.5.0958, 1980.

Rudd, J. W. M., Hamilton, R. D., and Campbell, N. E. R.: Measurement of microbial oxidation of methane in lake water, Limnol. Oceanogr., 19, 519-524, doi:10.4319/lo.1974.19.3.0519, 1974.

Saunois, M., Bousquet, P., Poulter, B., Peregon, A., Ciais, P., Canadell, J. G., Dlugokencky, E. J., Etiope, G., Bastviken, D., Houweling, S., Janssens-Maenhout, G., Tubiello, F. N., Castaldi, S., Jackson, R. B., Alexe, M., Arora, V. K., Beerling, D. J., Bergamaschi, P., Blake, D. R., Brailsford, G., Brovkin, V., Bruhwiler, L., Crevoisier, C., Crill, P., Curry, C., Frankenberg, C., Gedney, N., Höglund-Isaksson, L., Ishizawa, M., Ito, A., Joos, F., Kim, H. S., Kleinen, T., Krummel, P., Lamarque, J. F., Langenfelds, R., Locatelli, R., Machida, T., Maksyutov, S., McDonald, K. C., Marshall, J., Melton, J. R., Morino, I., O'Doherty, S., Parmentier, F. J. W., Patra, P. K., Peng, C., Peng, S., Peters, G. P., Pison, I., Prigent, C., Prinn, R., Ramonet, M., Riley, W. J., Saito, M., Schroeder, R., Simpson, I. J., Spahni, R., Steele, P., Takizawa, A., Thornton, B. F., Tian, H., Tohjima, Y., Viovy, N., Voulgarakis, A., van Weele, M., van der Werf, G., Weiss, R., Wiedinmyer, C., Wilton, D. J., Wiltshire, A., Worthy, D., Wunch, D. B., Xu, X., Yoshida, Y., Zhang, B., Zhang, Z., and Zhu, Q.: The Global Methane Budget: 2000-2012, Earth Syst. Sci. Data Discuss., 2016, 1-79, doi:10.5194/essd-2016-25, 2016.

Sturm, A., Fowle, D. A., Jones, C., Leslie, K., Nomosatryo, S., Henny, C., Canfield, D. E., and Crowe, S. A.: Rates and pathways of $\mathrm{CH} 4$ oxidation in ferruginous Lake Matano, Indonesia, Biogeosciences Discuss., 2016, 1-34, doi:10.5194/bg-2015-533, 2016.

Thamdrup, B., and Dalsgaard, T.: Production of N2 through anaerobic ammonium oxidation coupled to nitrate reduction in marine sediments, Appl. Environ. Microbiol., 68, 1312-1318, doi:10.1128/AEM.68.3, 2002.

Weiss, R. F., and Price, B. A.: Nitrous oxide solubility in water and seawater, Mar. Chem., 8, 347-359, doi:10.1016/0304-4203(80)90024-9, 1980.

Weiss, R. F.: Determinations of carbon dioxide and methane by dual catalyst flame ionization chromatography and nitrous oxide by electron capture chromatography, J. Chromatogr. Sci., 19, 611-616, doi:10.1093/chromsci/19.12.611, 1981.

Westermann, P., and Ahring, B. K.: Dynamics of methane production, sulfate reduction, and denitrification in a permanently waterlogged alder swamp, Appl. Environ. Microbiol., 53, 2554-2559, 1987.

Yamamoto, S., Alcauskas, J. B., and Crozier, T. E.: Solubility of methane in distilled water and seawater, J. Chem. Eng. Data, 21, 78-80, doi:10.1021/je60068a029, 1976. 
Biogeosciences Discuss., doi:10.5194/bg-2016-300, 2016

Manuscript under review for journal Biogeosciences

Published: 21 July 2016

(c) Author(s) 2016. CC-BY 3.0 License.

Table 1: Depth (m) where $\mathrm{CH}_{4}$ oxidation was observed, presence (+) or absence (-) of oxygen $\left(\mathrm{O}_{2}\right), \mathrm{CH}_{4}$ oxi $=$ maximum $\mathrm{CH}_{4}$ oxidation rates $\left(\mu \mathrm{mol} \mathrm{L} \mathrm{L}^{-1} \mathrm{~d}^{-1}\right)$ calculated based on a linear regression, $\left[\mathrm{CH}_{4}\right]_{\text {in }}=$ initial $\mathrm{CH}_{4}$ concentrations $\left(\mu \mathrm{mol} \mathrm{L}^{-1}\right)$ from which the linear regression begins, $\% \mathrm{CH}_{4}=$ percentage of initial $\mathrm{CH}_{4}$ consumed, and time (h) required for this consumption (time lapse during which the linear regression was applied to calculate $\mathrm{CH}_{4}$ oxidation rates), without and with molybdate added (- Mo and + Mo, respectively), for all field campaigns. N.d. = not determined.

\begin{tabular}{|c|c|c|c|c|c|c|c|c|c|}
\hline \multirow[t]{2}{*}{$\begin{array}{c}\text { Depth } \\
\text { (m) }\end{array}$} & \multirow[t]{2}{*}{$\mathbf{O}_{2}$} & \multicolumn{2}{|c|}{$\begin{array}{c}\mathrm{CH}_{4} \text { oxi } \\
\left(\mu \mathrm{mol} \mathrm{L} \mathbf{L}^{-1} \mathbf{d}^{-1}\right)\end{array}$} & \multicolumn{2}{|c|}{ 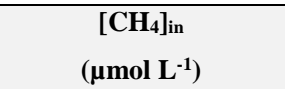 } & \multicolumn{2}{|c|}{$\% \mathrm{CH}_{4}$} & \multicolumn{2}{|c|}{$\begin{array}{c}\text { Time } \\
\text { (h) }\end{array}$} \\
\hline & & - Mo & + Mo & - Mo & + Mo & - Mo & + Mo & - Mo & + Mo \\
\hline \multicolumn{10}{|c|}{ June 2011} \\
\hline 42.5 & + & $0.3 \pm 0.0$ & N.d. & $0.3 \pm 0$ & N.d. & $90 \pm 0$ & N.d. & 24 & N.d. \\
\hline 45 & + & $2.0 \pm 0.0$ & N.d. & $2 \pm 0$ & N.d. & $97 \pm 0$ & N.d. & 24 & N.d. \\
\hline 47.5 & - & $0.8 \pm 0.0$ & N.d. & $18 \pm 0$ & N.d. & $23 \pm 0$ & N.d. & 96 & N.d. \\
\hline 50 & - & $0.4 \pm 0.1$ & N.d. & $21 \pm 0$ & N.d. & $10 \pm 0$ & N.d. & 96 & N.d. \\
\hline \multicolumn{10}{|c|}{ February 2012} \\
\hline 45 & - & $0.3 \pm 0.0$ & $0.1 \pm 0.0$ & $1 \pm 0$ & $1 \pm 0$ & $73 \pm 0$ & $66 \pm 0$ & 72 & 72 \\
\hline 50 & - & $7.7 \pm 0.4$ & $3.0 \pm 0.3$ & $8 \pm 0$ & $8 \pm 0$ & $64 \pm 1$ & $27 \pm 2$ & 16 & 16 \\
\hline 55 & - & $4.0 \pm 0.2$ & $4.3 \pm 0.0$ & $21 \pm 0$ & $21 \pm 0$ & $12 \pm 1$ & $13 \pm 0$ & 16 & 16 \\
\hline 60 & - & 1.2 & 0.2 & 115 & 105 & 4 & 3 & 72 & 96 \\
\hline \multicolumn{10}{|c|}{ October 2012} \\
\hline 53 & + & $10.2 \pm 0.4$ & $10.0 \pm 0.4$ & $10 \pm 0$ & $10 \pm 0$ & $98 \pm 0$ & $97 \pm 0$ & 24 & 24 \\
\hline 55 & + & $0.4 \pm 0.4$ & $16.9 \pm 5.4$ & $78 \pm 4$ & $78 \pm 4$ & $2 \pm 6$ & $18 \pm 5$ & 96 & 24 \\
\hline 57.5 & - & $0.2 \pm 0.2$ & $1.3 \pm 0.5$ & $65 \pm 3$ & $65 \pm 3$ & $4 \pm 5$ & $10 \pm 5$ & 96 & 96 \\
\hline 60 & - & $0 \pm 0$ & $2.1 \pm 2.5$ & $129 \pm 17$ & $129 \pm 17$ & $0 \pm 0$ & $10 \pm 12$ & 96 & 96 \\
\hline 70 & - & $0 \pm 0$ & $1.3 \pm 1.6$ & $344 \pm 11$ & $344 \pm 11$ & $0 \pm 0$ & $2 \pm 3$ & 96 & 96 \\
\hline 80 & - & $0 \pm 0$ & $23.4 \pm 0.4$ & $538 \pm 2$ & $538 \pm 2$ & $0 \pm 0$ & $26 \pm 0$ & 96 & 96 \\
\hline \multicolumn{10}{|c|}{ May 2013} \\
\hline 40 & + & $0.1 \pm 0.0$ & N.d. & $0.4 \pm 0$ & N.d. & $45 \pm 2$ & N.d. & 96 & N.d. \\
\hline 45 & + & $0.1 \pm 0.0$ & N.d. & $0.7 \pm 0$ & N.d. & $63 \pm 1$ & N.d. & 72 & N.d. \\
\hline 47.5 & + & $0.6 \pm 0.0$ & $0.6 \pm 0.0$ & $2 \pm 0$ & $2 \pm 0$ & $75 \pm 1$ & $75 \pm 1$ & 48 & 48 \\
\hline 50 & + & $1.5 \pm 0.2$ & $1.0 \pm 0.3$ & $20 \pm 1$ & $20 \pm 1$ & $31 \pm 4$ & $18 \pm 5$ & 96 & 72 \\
\hline 52.5 & + & $0.5 \pm 0.1$ & $0.3 \pm 0.0$ & $25 \pm 0$ & $25 \pm 0$ & $7 \pm 1$ & $7 \pm 1$ & 72 & 96 \\
\hline 55 & - & 1.2 & $4.5 \pm 4.2$ & 45 & $45 \pm 4$ & 8 & $8 \pm 7$ & 96 & 24 \\
\hline 60 & - & 1.0 & $6.0 \pm 5.6$ & 115 & $113 \pm 4$ & 4 & $4 \pm 4$ & 96 & 24 \\
\hline 65 & - & 3.2 & 18.0 & 227 & 223 & 6 & 6 & 96 & 24 \\
\hline 70 & - & $1.5 \pm 0.3$ & $1.0 \pm 0.0$ & $410 \pm 3$ & $410 \pm 3$ & $2 \pm 1$ & $2 \pm 1$ & 120 & 120 \\
\hline \multicolumn{10}{|c|}{ September 2013} \\
\hline 40 & + & 0.02 & N.d. & 0.2 & N.d. & 37 & N.d. & 48 & N.d. \\
\hline 45 & + & $0.02 \pm 0.0$ & $0.0 \pm 0.0$ & $0.1 \pm 0$ & $0.1 \pm 0$ & $73 \pm 3$ & $0 \pm 0$ & 96 & 96 \\
\hline
\end{tabular}


Biogeosciences Discuss., doi:10.5194/bg-2016-300, 2016

Manuscript under review for journal Biogeosciences

Published: 21 July 2016

(c) Author(s) 2016. CC-BY 3.0 License.

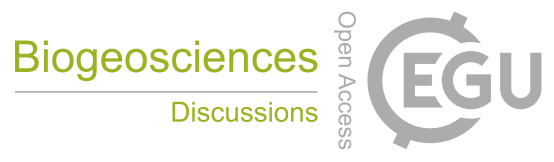

(c) $\underset{\mathrm{BY}}{\mathrm{B}}$

\begin{tabular}{c|c|cc|cc|cc|c|c}
47.5 & + & $13.4 \pm 0.3$ & $10.5 \pm 0.3$ & $13 \pm 0$ & $13 \pm 0$ & $93 \pm 0$ & $75 \pm 1$ & 24 & 24 \\
50 & + & $13.9 \pm 0.0$ & $12.7 \pm 0.0$ & $27 \pm 0$ & $27 \pm 0$ & $17 \pm 0$ & $16 \pm 0$ & 12 & 12 \\
52.5 & + & $0.2 \pm 0.0$ & $1.0 \pm 0.0$ & $50 \pm 0$ & $50 \pm 0$ & $2 \pm 0$ & $11 \pm 0$ & 96 & 96 \\
55 & - & $0.5 \pm 0.0$ & $11.3 \pm 0.5$ & $90 \pm 0$ & $90 \pm 0$ & $2 \pm 0$ & $4 \pm 0$ & 72 & 12 \\
57.5 & - & $0.3 \pm 0.0$ & $10.2 \pm 0.4$ & $99 \pm 0$ & $99 \pm 0$ & $3 \pm 0$ & $3 \pm 0$ & 96 & 12 \\
65 & - & $3.5 \pm 0.3$ & $2.6 \pm 0.3$ & $215 \pm 1$ & $215 \pm 1$ & $6 \pm 1$ & $5 \pm 1$ & 72 & 72 \\
& & & & & August 2014 & & & & \\
55 & + & $27.1 \pm 1.6$ & $18.0 \pm 1.6$ & $42 \pm 2$ & $42 \pm 2$ & $68 \pm 1$ & $46 \pm 3$ & 24 & 24 \\
57.5 & + & 2.1 & 1.5 & 69 & 69 & 6 & 4 & 48 & 48 \\
60 & - & $0.0 \pm 0.0$ & 4.7 & $167 \pm 20$ & $167 \pm 20$ & $0 \pm 0$ & 6 & 96 & 48 \\
65 & - & $5.1 \pm 0.9$ & $1.3 \pm 0.9$ & $275 \pm 1$ & $275 \pm 1$ & $6 \pm 2$ & $3 \pm 2$ & 96 & 96 \\
67.5 & - & $6.8 \pm 7.8$ & $0.0 \pm 0.0$ & $358 \pm 6$ & $358 \pm 6$ & $16 \pm 12$ & $0 \pm 0$ & 96 & 96 \\
70 & - & $3.3 \pm 1.3$ & $0.0 \pm 0.0$ & $445 \pm 10$ & $445 \pm 10$ & $6 \pm 2$ & $0 \pm 0$ & 96 & 96 \\
75 & - & $16.0 \pm 8.2$ & $0.0 \pm 0.0$ & $689 \pm 58$ & $689 \pm 58$ & $3 \pm 8$ & $0 \pm 0$ & 96 & 96 \\
\hline
\end{tabular}


Biogeosciences Discuss., doi:10.5194/bg-2016-300, 2016

Manuscript under review for journal Biogeosciences

Published: 21 July 2016

(c) Author(s) 2016. CC-BY 3.0 License.

Table 2: Anoxic depths (m), $\mathrm{NO}_{3}{ }^{-}$and $\mathrm{SO}_{4}{ }^{2-}$ consumption and $\mathrm{Mn}^{2+}$ production rates $\left(\mu \mathrm{mol} \mathrm{L} \mathrm{L}^{-1} \mathrm{~d}^{-1}\right)$ and their standard deviation, without and with molybdate added ( Mo and + Mo, respectively), for all campaigns. N.d. $=$ not determined. All rates were calculated based on a linear regression of concentrations through time.

\begin{tabular}{|c|c|c|c|c|c|c|}
\hline \multirow[t]{2}{*}{ Depth (m) } & \multicolumn{2}{|c|}{$\begin{array}{c}\mathrm{NO}_{3}^{-} \text {consumption } \\
\left(\mu \mathrm{mol} \mathrm{L}^{-1} \mathbf{d}^{-1}\right)\end{array}$} & \multicolumn{2}{|c|}{$\begin{array}{c}\mathrm{SO}_{4}{ }^{2-} \text { consumption } \\
\left(\mu \mathrm{mol} \mathrm{L} \mathbf{L}^{-1} \mathbf{d}^{-1}\right)\end{array}$} & \multicolumn{2}{|c|}{$\begin{array}{c}\mathrm{Mn}^{2+} \text { production } \\
\left(\mu \mathrm{mol} \mathrm{L} \mathbf{L}^{-1} \mathbf{d}^{-1}\right)\end{array}$} \\
\hline & - Mo & + Mo & - Mo & + Mo & - Mo & + Mo \\
\hline \multicolumn{7}{|c|}{ February 2012} \\
\hline 45 & $0.01 \pm 0.01$ & $0 \pm 0$ & N.d. & N.d. & N.d. & N.d. \\
\hline 50 & $0.37 \pm 0.07$ & $0.56 \pm 0.02$ & N.d. & N.d. & N.d. & N.d. \\
\hline 55 & $0.21 \pm 0.02$ & $0 \pm 0$ & N.d. & N.d. & N.d. & N.d. \\
\hline 60 & $0.01 \pm 0$ & $0.33 \pm 0$ & N.d. & N.d. & N.d. & N.d. \\
\hline \multicolumn{7}{|c|}{ October 2012} \\
\hline 57.5 & $0 \pm 0$ & $0 \pm 0$ & N.d. & N.d. & N.d. & N.d. \\
\hline 60 & 0 & 0.02 & N.d. & N.d. & N.d. & N.d. \\
\hline 65 & 0 & 0.04 & N.d. & N.d. & N.d. & N.d. \\
\hline 70 & 0 & 0.04 & N.d. & N.d. & N.d. & N.d. \\
\hline \multicolumn{7}{|c|}{ May 2013} \\
\hline 55 & $0 \pm 0$ & $0 \pm 0$ & N.d. & N.d. & N.d. & N.d. \\
\hline 60 & 0.07 & 0 & N.d. & N.d. & N.d. & N.d. \\
\hline 65 & $0 \pm 0$ & $0 \pm 0$ & N.d. & N.d. & N.d. & N.d. \\
\hline 70 & $0.03 \pm 0.01$ & $0.25 \pm 0.05$ & N.d. & N.d. & N.d. & N.d. \\
\hline \multicolumn{7}{|c|}{ September 2013} \\
\hline 55 & $0 \pm 0$ & $0 \pm 0$ & N.d. & N.d. & N.d. & N.d. \\
\hline 57.5 & $0 \pm 0$ & $0 \pm 0$ & N.d. & N.d. & N.d. & N.d. \\
\hline 65 & $0 \pm 0$ & $0.04 \pm 0.01$ & N.d. & N.d. & N.d. & N.d. \\
\hline \multicolumn{7}{|c|}{ August 2014} \\
\hline 60 & $0 \pm 0$ & $0 \pm 0$ & $1.0 \pm 0.5$ & N.d. & $0 \pm 0$ & $0 \pm 0$ \\
\hline 62.5 & $0 \pm 0$ & $0 \pm 0$ & $0.7 \pm 0.3$ & N.d. & $0 \pm 0$ & $0.5 \pm 0.2$ \\
\hline 65 & $0 \pm 0$ & $0 \pm 0$ & $0 \pm 0$ & N.d. & $0 \pm 0$ & $0 \pm 0$ \\
\hline 67.5 & $0 \pm 0$ & $0 \pm 0$ & $1.5 \pm 0.6$ & N.d. & $0 \pm 0$ & $10.6 \pm 1.6$ \\
\hline 70 & $0 \pm 0$ & $0 \pm 0$ & $17.5 \pm 5.8$ & N.d. & $0 \pm 0$ & $8.1 \pm 0.1$ \\
\hline 75 & $0 \pm 0$ & $0 \pm 0$ & $0.3 \pm 0.03$ & N.d. & $0 \pm 0$ & $0 \pm 0$ \\
\hline
\end{tabular}


Biogeosciences Discuss., doi:10.5194/bg-2016-300, 2016

Manuscript under review for journal Biogeosciences

Published: 21 July 2016

(c) Author(s) 2016. CC-BY 3.0 License.

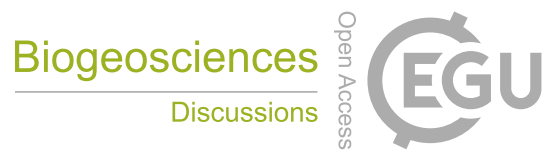

(c) (i)

Table 3: Depth-integrated $\mathrm{CH}_{4}$ oxidation rates $\left(\mu \mathrm{mol} \mathrm{m} \mathrm{m}^{-2} \mathrm{~d}^{-1}\right)$ in Lake Kivu and the percent related to anaerobic oxidation of methane (AOM).

\begin{tabular}{|c|c|c|c|}
\hline & $\begin{array}{c}\text { Integration depth } \\
\text { interval (m) }\end{array}$ & $\begin{array}{l}\text { CH4 oxidation } \\
\left(\mu \mathrm{mol} \mathrm{m}^{-2} \mathbf{d}^{-1}\right)\end{array}$ & $\%$ AOM \\
\hline \multicolumn{4}{|c|}{ Dry season } \\
\hline June 2011 & $1-65$ & 9 & 30 \\
\hline October 2012 & $1-80$ & 27 & 1 \\
\hline September 2013 & $1-65$ & 81 & 15 \\
\hline August 2014 & $1-75$ & 162 & 55 \\
\hline \multicolumn{4}{|c|}{ Rainy season } \\
\hline February 2012 & $1-60$ & 63 & 99 \\
\hline May 2013 & $1-80$ & 44 & 81 \\
\hline
\end{tabular}


Biogeosciences Discuss., doi:10.5194/bg-2016-300, 2016

Manuscript under review for journal Biogeosciences

Published: 21 July 2016

(c) Author(s) 2016. CC-BY 3.0 License.

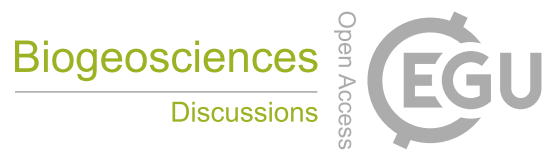

(c) (i)

Table 4: Aerobic and anaerobic $\mathrm{CH}_{4}$ oxidation rates $\left(\mu \mathrm{mol} \mathrm{L} \mathrm{L}^{-1} \mathrm{~d}^{-1}\right)$ in Lake Kivu and other lakes in literature.

\begin{tabular}{|c|c|c|c|}
\hline Lake & 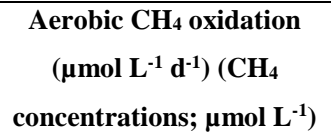 & 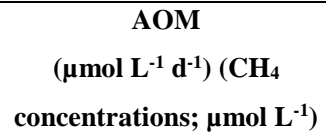 & Source \\
\hline Kivu & $0.02-27(0.2-42)$ & $0.2-16(65-689)$ & This study \\
\hline Pavin (France) & $0.006-0.046(0.06-0.35)$ & $0.4(285-785)$ & Lopes et al. (2011) \\
\hline Big Soda (US) & $0.0013(0.1)$ & $0.060(50)$ & Iversen et al. (1987) \\
\hline Marn (Sweden) & $0.8(10)$ & $2.2(55)$ & Bastviken et al. (2002) \\
\hline Tanganyika & $0.1-0.96(<10)$ & $0.24-1.8(\sim 10)$ & Rudd (1980) \\
\hline Matano (Indonesia) & $0.00036-0.0025(0.5)$ & $4.2-117(12-484)$ & Sturm et al. (2016) \\
\hline
\end{tabular}


Biogeosciences Discuss., doi:10.5194/bg-2016-300, 2016

Manuscript under review for journal Biogeosciences

Published: 21 July 2016

(c) Author(s) 2016. CC-BY 3.0 License.

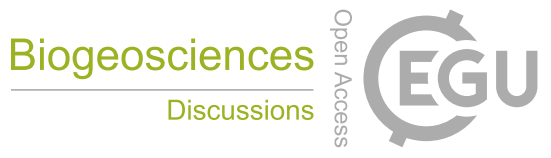

(c) (i)

Table 5: $\mathrm{SO}_{4}{ }^{2-}, \mathrm{NO}_{\mathrm{x}}, \mathrm{Mn}^{2+}$ and $\mathrm{MnO}_{2}$ concentrations $\left(\mu \mathrm{mol} \mathrm{L}{ }^{-1}\right.$ ) and potential anaerobic $\mathrm{CH}_{4}$ oxidation (\%) based on these concentrations for all campaigns, for each depth where AOM rates were observed. N.d. $=$ not determined.

\begin{tabular}{|c|c|c|c|c|c|}
\hline Field campaign & Depth (m) & $\begin{array}{c}\mathrm{SO}_{4}{ }^{2-} \text { concentrations } \\
\left(\mu \mathrm{mol} \mathrm{L}{ }^{-1}\right)(\%)\end{array}$ & $\begin{array}{c}\text { NOx concentrations } \\
\quad\left(\mu \mathrm{mol} \mathrm{L} \mathbf{L}^{-1}\right)(\%)\end{array}$ & $\begin{array}{c}\mathrm{Mn}^{2+} \\
\text { concentrations } \\
\left(\mu \mathrm{mol} \mathrm{L}^{-1}\right)(\%)\end{array}$ & $\begin{array}{c}\mathrm{MnO}_{2} \\
\text { concentrations } \\
\left.(\mu \mathrm{mol} \mathrm{L})^{-1}\right)(\%)\end{array}$ \\
\hline \multirow[t]{2}{*}{ June 2011} & 47.5 & $125.6(100)$ & $0.23(18)$ & N.d. & N.d. \\
\hline & 50 & $158.8(100)$ & $0.24(38)$ & N.d. & N.d. \\
\hline \multirow[t]{4}{*}{ February 2012} & 45 & $168.5(100)$ & $1.84(100)$ & N.d. & N.d. \\
\hline & 47.5 & $160.9(100)$ & $1.08(9)$ & N.d. & N.d. \\
\hline & 50 & $108.4(100)$ & $0.04(1)$ & N.d. & N.d. \\
\hline & 55 & $77.0(100)$ & $0.38(20)$ & N.d. & N.d. \\
\hline October 2012 & 57.5 & N.d. & $0.53(100)$ & N.d. & N.d. \\
\hline \multirow[t]{4}{*}{ May 2013} & 55 & $130.4(100)$ & $0.04(2)$ & $3.0(63)$ & $0.2(100)$ \\
\hline & 60 & $135.4(100)$ & $0.15(9)$ & $5.5(100)$ & $0.2(100)$ \\
\hline & 65 & $112.2(100)$ & $0.11(2)$ & $7.3(57)$ & $0.2(45)$ \\
\hline & 70 & $47.5(100)$ & $0.2(8)$ & $8.0(100)$ & N.d. \\
\hline \multirow[t]{3}{*}{ September 2013} & 55 & $130.5(100)$ & $0.91(100)$ & $8.7(100)$ & $0.7(100)$ \\
\hline & 57.5 & $124.1(100)$ & $0.43(90)$ & $9.2(100)$ & $0.8(100)$ \\
\hline & 60 & $108.1(100)$ & $0.43(8)$ & $9.5(68)$ & N.d. \\
\hline \multirow[t]{4}{*}{ August 2014} & 65 & $60.6(100)$ & $0.20(2)$ & $8.8(43)$ & N.d. \\
\hline & 67.5 & $45.5(100)$ & $0.00(0)$ & $9.2(34)$ & N.d. \\
\hline & 70 & $25.6(100)$ & $0.33(6)$ & $9.3(70)$ & N.d. \\
\hline & 75 & $10.7(67)$ & $0.13(1)$ & $9.4(15)$ & N.d. \\
\hline
\end{tabular}


Biogeosciences Discuss., doi:10.5194/bg-2016-300, 2016

Manuscript under review for journal Biogeosciences

Published: 21 July 2016

(c) Author(s) 2016. CC-BY 3.0 License.

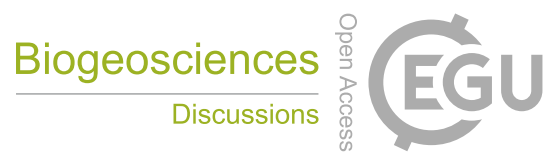

(c) (i)

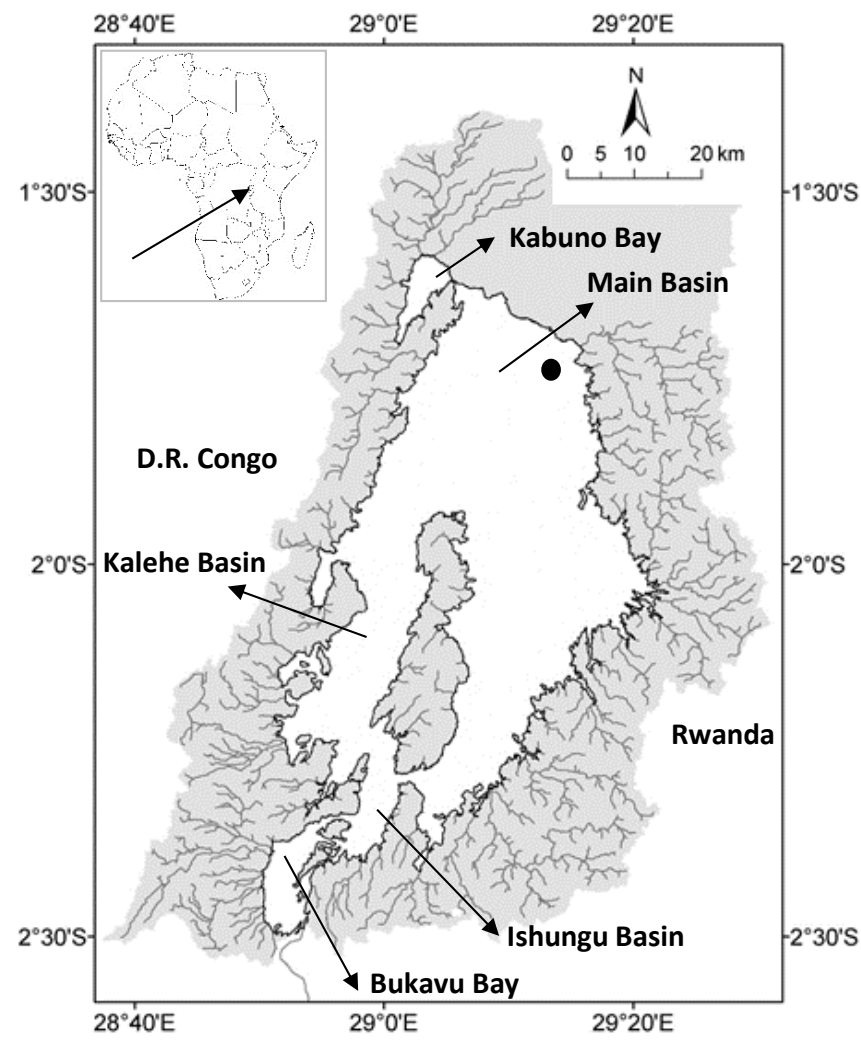

Figure 1: Map of Lake Kivu, showing the different basins and bays, and the sampling site in the main basin (black plot). 
Biogeosciences Discuss., doi:10.5194/bg-2016-300, 2016

Manuscript under review for journal Biogeosciences

Published: 21 July 2016

(c) Author(s) 2016. CC-BY 3.0 License.

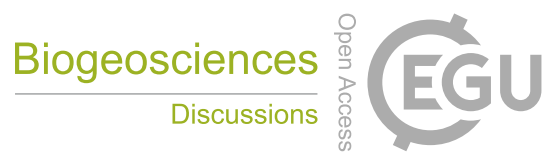

\section{(c) (1)}
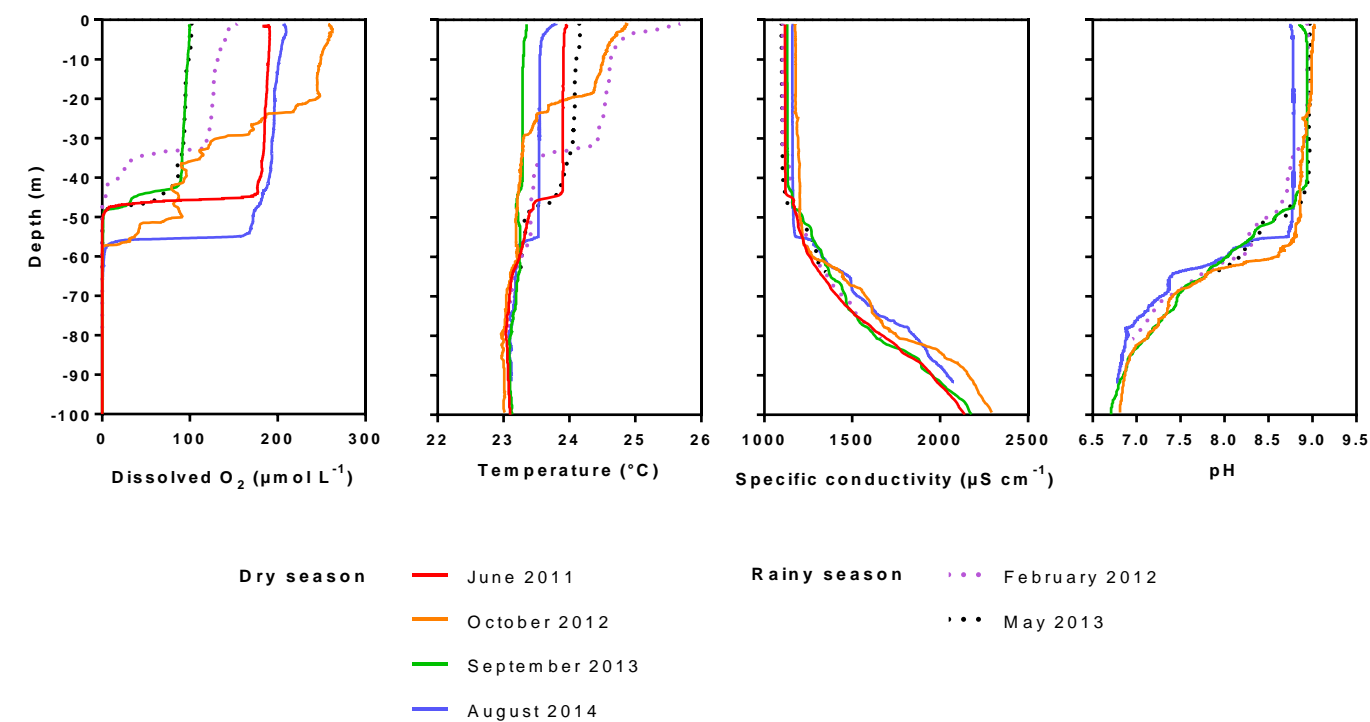

Rainy season … February 2012

... M ay 2013

Figure 2: Vertical profiles of dissolved oxygen $\left(\mu \mathrm{mol} \mathrm{L}{ }^{-1}\right)$, temperature $\left({ }^{\circ} \mathrm{C}\right)$, specific conductivity $\left(\mu \mathrm{S} \mathrm{cm}^{-1}\right)$ and $\mathrm{pH}$ for the six field campaigns. 
Biogeosciences Discuss., doi:10.5194/bg-2016-300, 2016

Manuscript under review for journal Biogeosciences

Published: 21 July 2016

(c) Author(s) 2016. CC-BY 3.0 License.
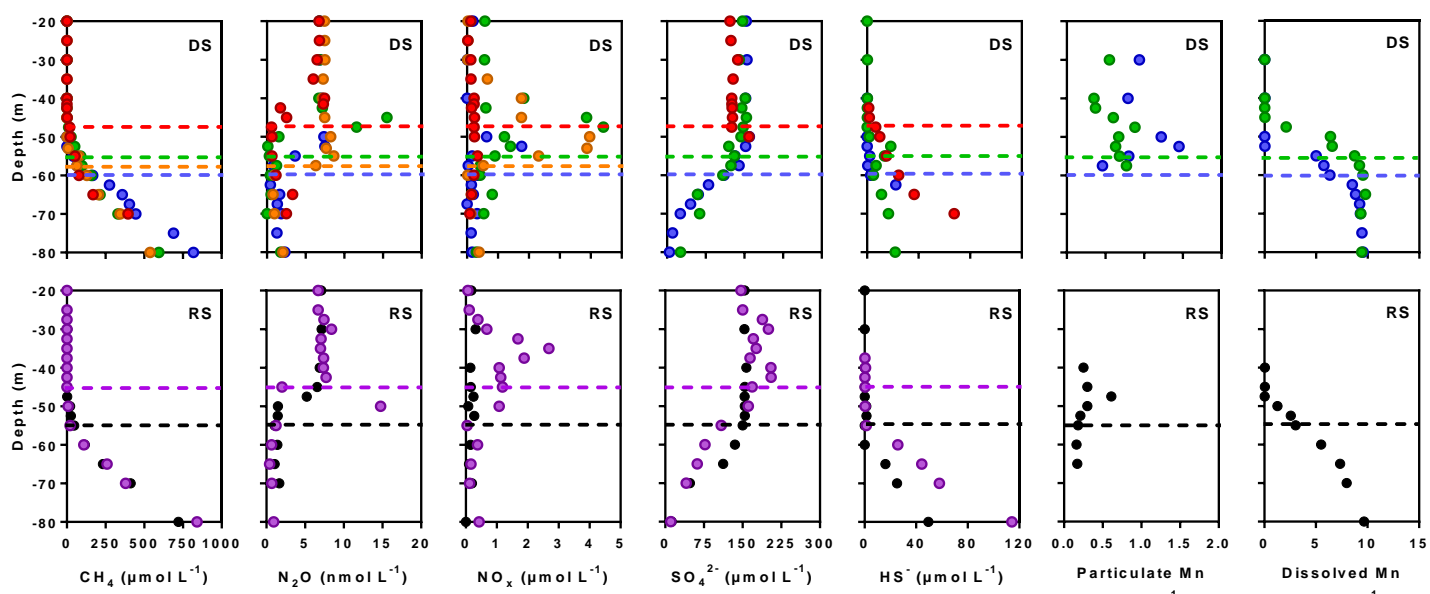

Particulate $\mathrm{Mn}$
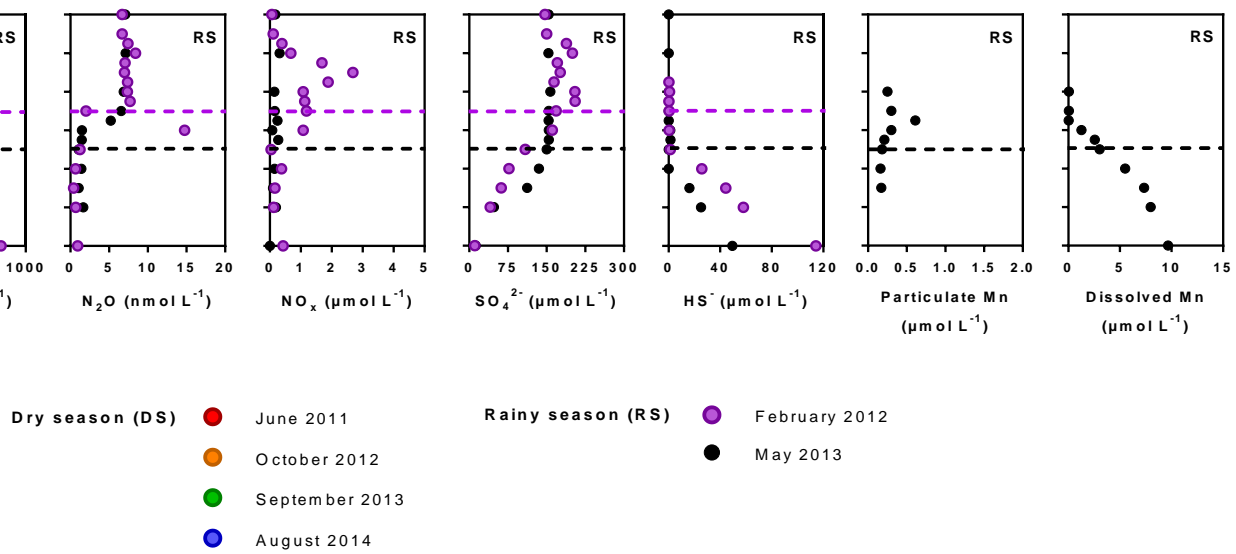

Rainy season (RS)

February 2012

- May 2013

- August 2014

Figure 3: Vertical profiles of $\mathrm{CH}_{4}\left(\mu \mathrm{mol} \mathrm{L}{ }^{-1}\right), \mathrm{N}_{2} \mathrm{O}(\mathrm{nmol} \mathrm{L}-1), \mathrm{NO}_{\mathrm{x}}\left(\mu \mathrm{mol} \mathrm{L} \mathrm{L}^{-1}\right), \mathrm{SO}_{4}{ }^{2-}\left(\mu \mathrm{mol} \mathrm{L}^{-1}\right), \mathrm{HS}^{-}\left(\mu \mathrm{mol} \mathrm{L}^{-1}\right)$ and particulate $\mathrm{Mn}\left(\mu \mathrm{mol} \mathrm{L}^{-1}\right)$ and dissolved $\mathrm{Mn}\left(\mu \mathrm{mol} \mathrm{L}^{-1}\right)$ concentrations for the six field campaigns. Horizontal dashed lines represent the anoxic layer for each season (same color code). 
Biogeosciences Discuss., doi:10.5194/bg-2016-300, 2016

Manuscript under review for journal Biogeosciences

Published: 21 July 2016

(c) Author(s) 2016. CC-BY 3.0 License.

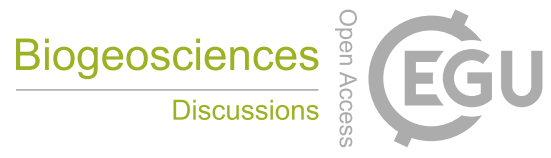

(c) (i)

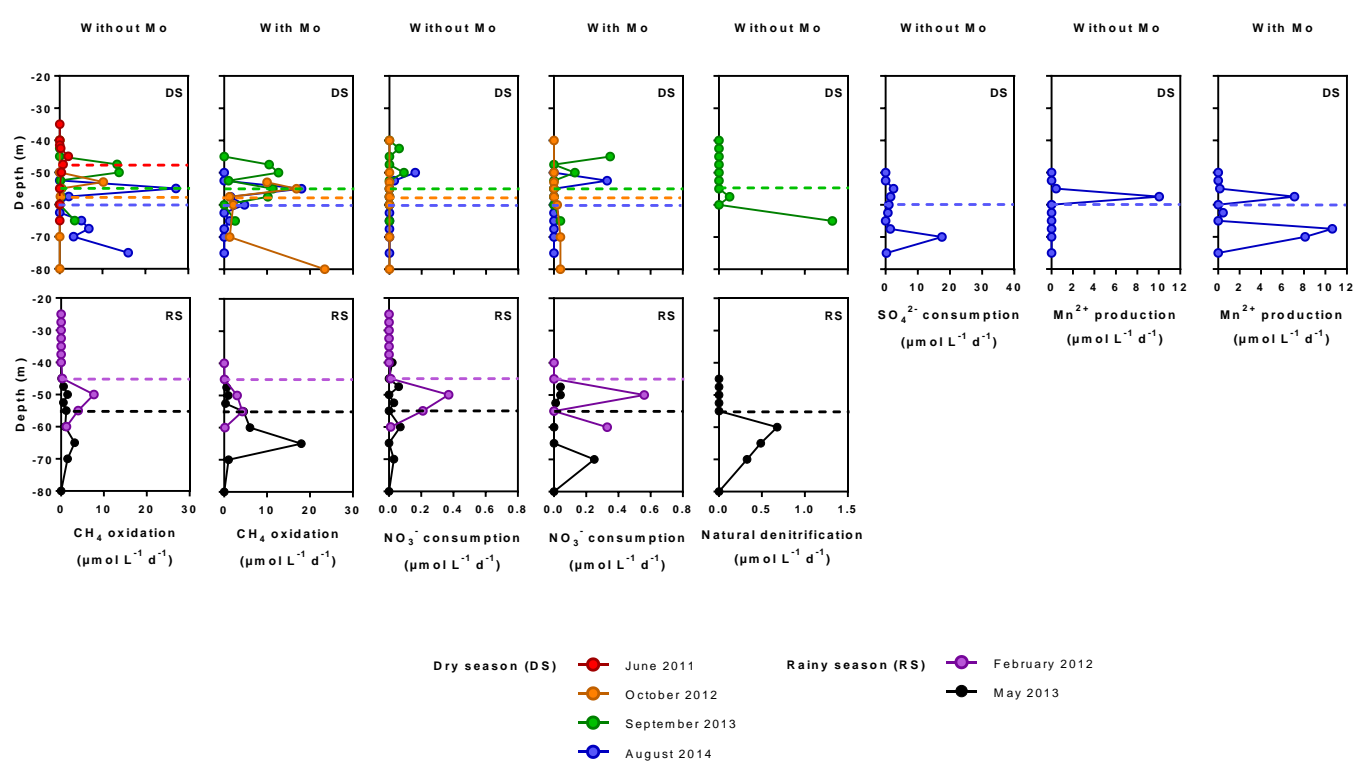

Figure 4: Process rates $\left(\mathrm{CH}_{4}\right.$ oxidation, $\mathrm{NO}_{3}{ }^{-}$consumption, Natural denitrification, $\mathrm{SO}_{4}{ }^{2-}$ consumption and dissolved $\mathrm{Mn}$ production; $\mu \mathrm{mol} \mathrm{L} \mathrm{L}^{-1} \mathrm{~d}^{-1}$ ) without and with molybdate (Mo) added, during the six field campaigns (DS: dry season; RS: rainy season). Horizontal dashed lines represent the anoxic layer for each season (same color code). 
Biogeosciences Discuss., doi:10.5194/bg-2016-300, 2016

Manuscript under review for journal Biogeosciences

Published: 21 July 2016

(c) Author(s) 2016. CC-BY 3.0 License.

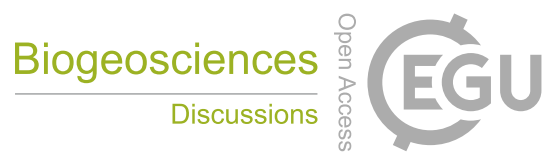

(c) (i)

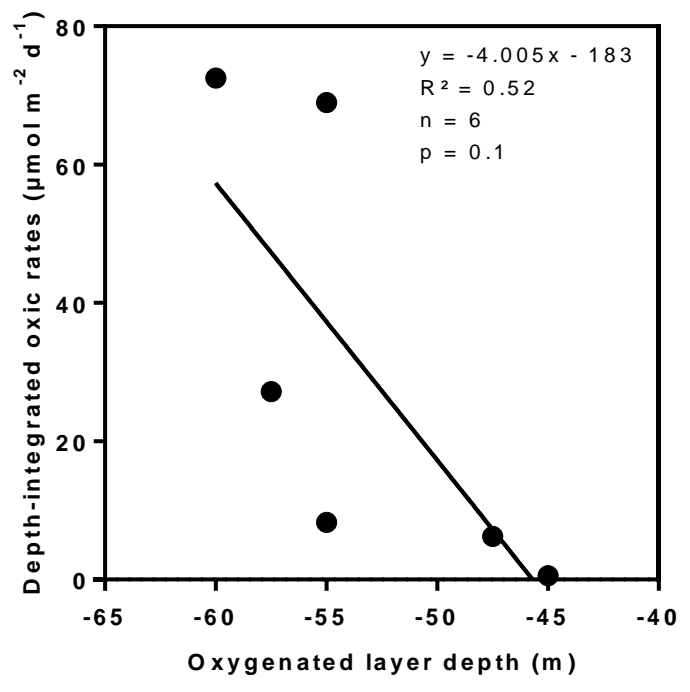

Figure 4: Depth-integrated aerobic $\mathrm{CH}_{4}$ oxidation rates $\left(\mu \mathrm{mol} \mathrm{m} \mathrm{m}^{-2} \mathrm{~d}^{-1}\right)$ compared to the oxygenated layer depth (m). 
Biogeosciences Discuss., doi:10.5194/bg-2016-300, 2016

Manuscript under review for journal Biogeosciences

Published: 21 July 2016

(c) Author(s) 2016. CC-BY 3.0 License.

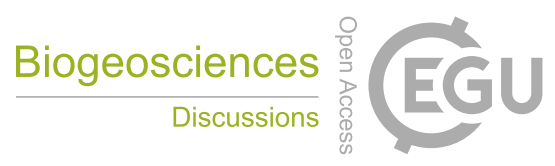

(c) $\underset{\mathrm{By}}{(\mathrm{i})}$

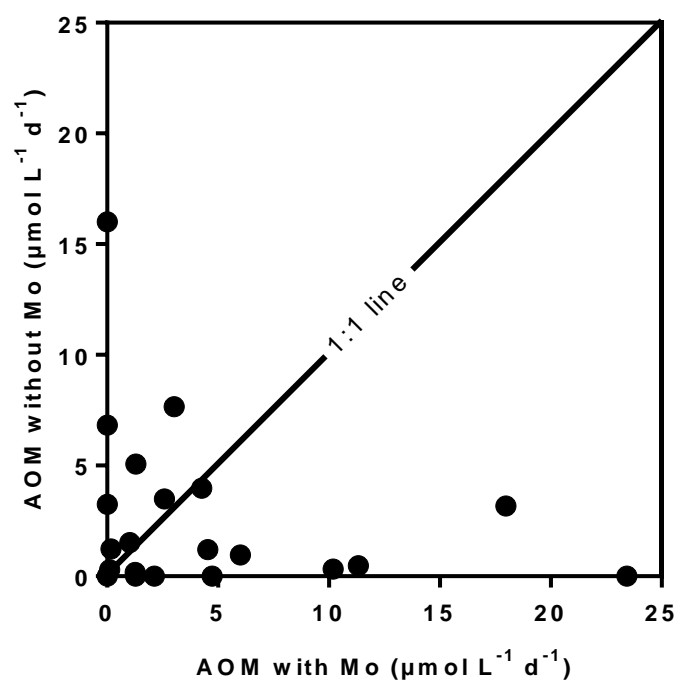

Figure 5: Comparison between AOM rates $\left(\mu \mathrm{mol} \mathrm{L}^{-1} \mathrm{~d}^{-1}\right)$ measured without and with molybdate (Mo) added. 
Biogeosciences Discuss., doi:10.5194/bg-2016-300, 2016

Manuscript under review for journal Biogeosciences

Published: 21 July 2016

(c) Author(s) 2016. CC-BY 3.0 License.

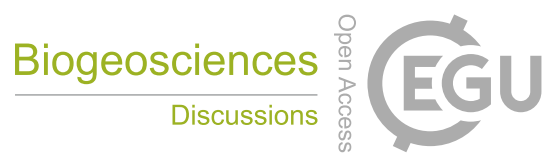

(c) (i)
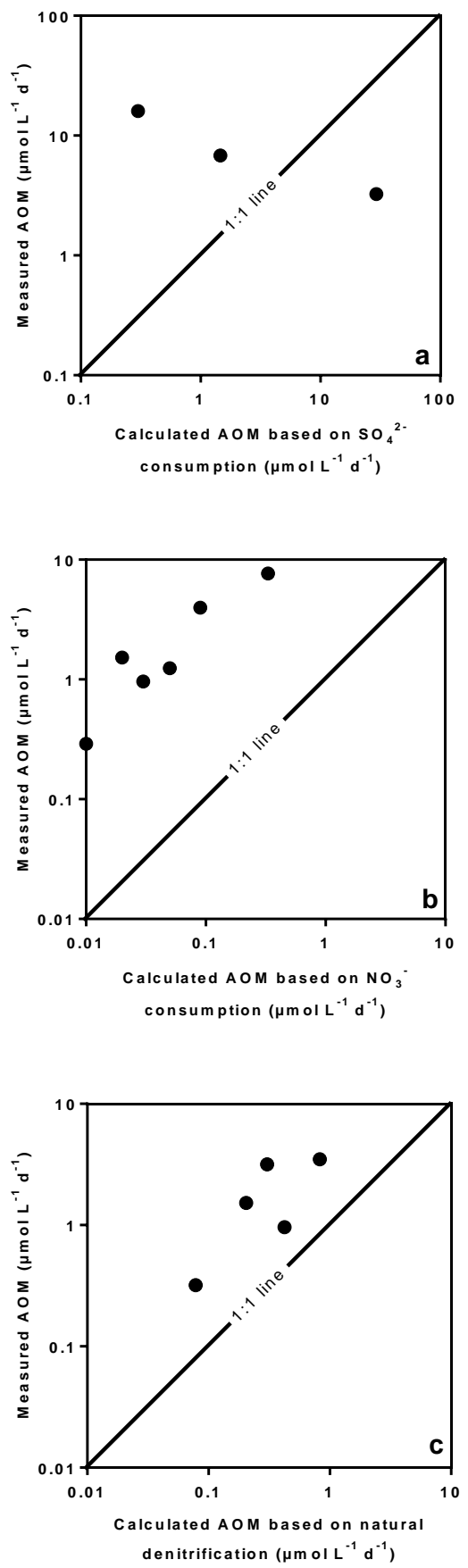

Figure 6: Comparison between measured and calculated AOM rates $\left(\mu \mathrm{mol} \mathrm{L}^{-1} \mathrm{~d}^{-1}\right)$ based on (a) $\mathrm{SO}_{4}{ }^{2-}$ - consumption rates, (b) $\mathrm{NO}_{3}{ }^{-}$consumption rates and (c) Natural denitrification. Note the log scales. 